ESSAYS ON CEO COMPENSATION

A Dissertation
presented to
the Faculty of the Graduate School
at the University of Missouri-Columbia
In Partial Fulfillment
of the Requirements for the Degree
Doctor of Philosophy
SCOTT O'BRIEN
br. John Howe, Dissertation Supervisor
MAY 2016


The undersigned, appointed by the dean of the Graduate School, have examined the dissertation entitled

\section{ESSAYS ON CEO COMPENSATION}

presented by Scott O’Brien,

a candidate for the degree of Ph.D. of Business Administration, and hereby certify that, in their opinion, it is worthy of acceptance.

\section{Professor John Howe}

Professor Oksana Loginova

Professor Stephen Ferris

Professor Dan French 


\section{ACKNOWLEDGEMENTS}

I would like to thank Professor John Howe, my advisor, for all the hours he spent providing invaluable guidance. I would like to thank my finance committee members, Professor Stephen Ferris and Professor Dan French, for being on my committee and providing feedback. Additionally, a special thanks to Professor Oksana Loginova for being my outside committee member. Finally, I would like to thank the faculty and staff in the College of Business for their support throughout my time here. 


\section{TABLE OF CONTENTS}

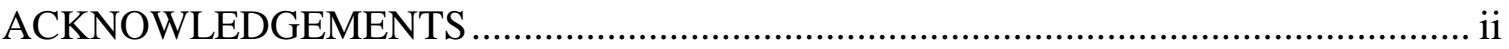

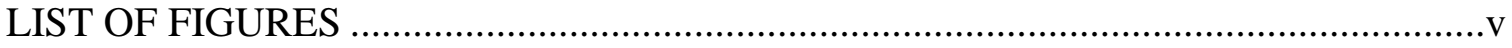

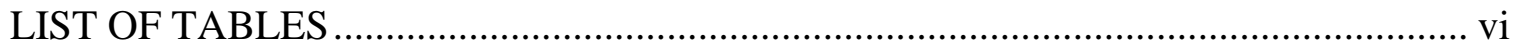

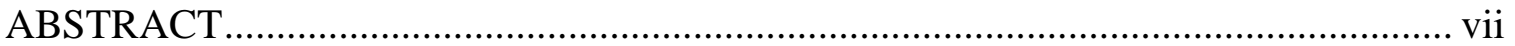

\section{Chapter}

1. CEO COMPENSATION PRACTICES AROUND SPINOFFS ...............................1

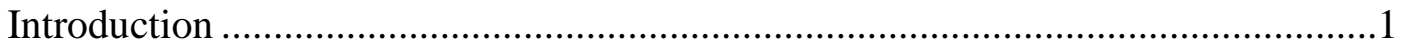

Relative Performance Evaluation, Asymmetry in Pay for Luck, and Compensation Benchmarking ..........................................................................................

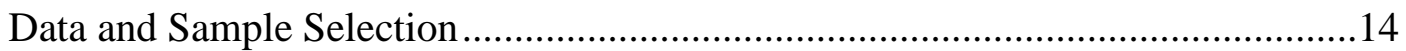

Empirical Tests and Results ...........................................................................16

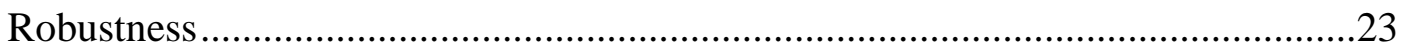

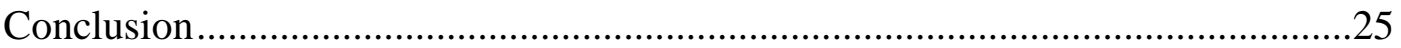

2. REFERENCE POINTS IN CEO COMPENSATION …………………................43

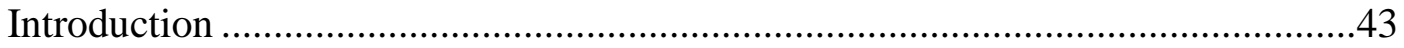

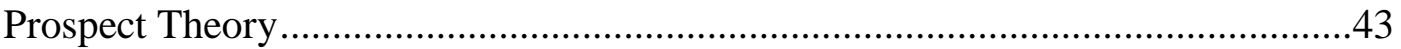

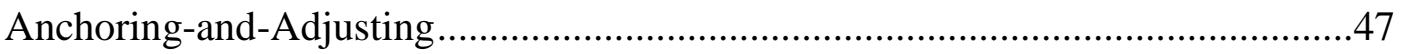

Testing Prospect Theory and Anchoring-and-Adjusting.........................................48

Data and Sample Selection...................................................................................52

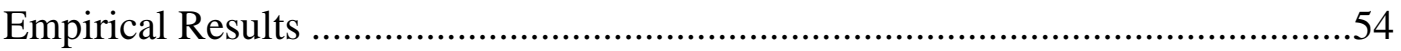

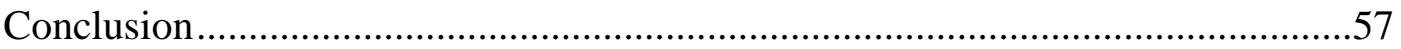




\section{APPENDIX}

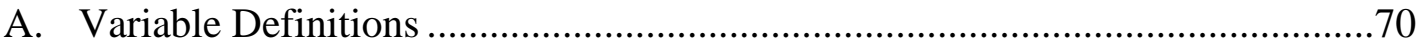

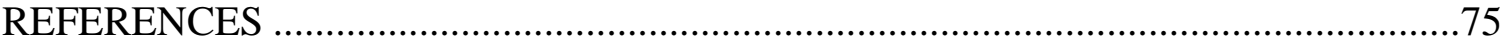

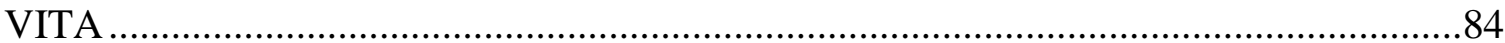




\section{LIST OF FIGURES}

\section{Chapter 2}

Figure 1: Prospect Theory Value Function ............................................................60 


\section{LIST OF TABLES}

\section{Chapter 1}

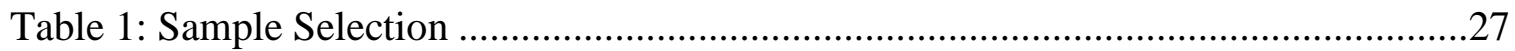

Table 2: Descriptive Statistics ...................................................................................28

Table 3: RPE pre- and post- spinoff parent firms …………………..................................32

Table 4: RPE pre- and post-spinoff using matched CEO sample .......................................33

Table 5: Pay for skill//uck in pre- and post-spinoff parent firms.........................................34

Table 6: Pay for skill/luck in pre- and post-spinoff firms using matched CEO sample ....35

Table 7: Asymmetry in pay for skill/luck for pre- and post-spinoff parent firms ..............36

Table 8: Asymmetry in pay for skill/luck using the matched CEO sample........................37

Table 9: Benchmarking CEO compensation with low compensation indicator ..................38

Table 10: Benchmarking CEO compensation with CDF measure .....................................39

Table 11: Matched sample descriptive statistics..............................................................40

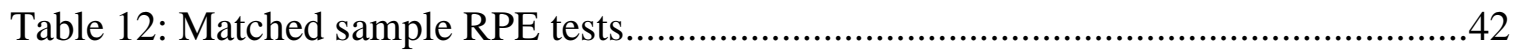

\section{Chapter 2}

Table 13: Compensation and performance by year relative to departure/arrival...............61

Table 14: CEO movers descriptive statistics ...................................................................62

Table 15: High and low change sample descriptive statistics............................................63

Table 16: CEO movers regression using industry/size compensation to calculate

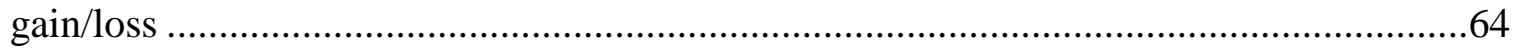

Table 17: CEO movers regression using a hedonic regression to calculate gain/loss .......65

Table 18: CEO movers correlation matrix ......................................................................66

Table 19: High and low change regressions using total compensation .............................67

Table 20: High and low change regressions using salary plus bonus ................................68

Table 21: High and low change correlation matrix ........................................................69 


\begin{abstract}
The two essays of my dissertation examine issues concerning CEO compensation. First, I examine the use of relative performance evaluation (RPE), asymmetry in pay for skill/luck, and compensation benchmarking for a sample of firms involved in a spinoff. The spinoff affects firm characteristics that influence the use of these compensation practices. I find that RPE is used for post-spinoff CEOs, but not pre-spinoff CEOs. This result is consistent with RPE being more prevalent as performance benchmark firms are easier to identify. Post-spinoff CEOs are also paid asymmetrically for luck where they are rewarded for good luck but not punished for bad luck. Both pre- and post- spinoff CEOs receive similar levels of compensation benchmarking.
\end{abstract}

Second, I study the role of reference points in CEO compensation. Using two samples, I identify multiple reference points and link the reference points to the behavioral phenomena of prospect theory and anchoring-and-adjusting. In a sample of CEOs who move from one company to another (mover sample), I estimate the CEOs' expected gain or loss in compensation as a result of the move, but do not find the effects of the expected gain or loss to be consistent with prospect theory preferences. Also in the mover sample, I find evidence of anchoring-and-adjusting where the compensation of the incoming CEO's predecessor (anchor) affects the compensation of the incoming CEO. Lastly, I find evidence that fiscal year high and low prices act as reference points where drops from the fiscal year high price to the fiscal year end price result in larger decreases in compensation than increases in compensation from the fiscal year low price to the fiscal year end price, consistent with prospect theory. 


\section{CHAPTER 1: CEO COMPENSATION PRACTICES AROUND SPINOFFS}

\section{Introduction}

A corporate spinoff occurs when a parent firm separates a business division by distributing shares of the division to its shareholders on a pro-rata basis. After the distribution, the parent firm and the firm created by the spinoff operate as separate companies and trade separately. I will refer to the pre-spinoff and continuing firm as the "parent," and the firm created by the spinoff as the "subsidiary," even though the parent no longer has a controlling interest in the subsidiary after the spinoff.

A recent example of a spinoff occurred on June 30, 2011, when Marathon Oil Corporation spun off its downstream (refining) division, which was renamed Marathon Petroleum Corporation. The CEO of Marathon Oil, Clarence Cazalot, Jr., remained as CEO of Marathon Oil after the spinoff. Gary Heminger, former executive vice president of the downstream division at Marathon Oil, was appointed CEO of Marathon Petroleum Corporation.

Unlike other forms of divestitures, spinoffs involve no cash exchanges and thus are not motivated by a company's cash requirements. Spinoffs are received well by the market, with an average abnormal return of $3 \%$ around the announcement date (Hite and Owers, 1983; Miles and Rosenfeld, 1983; Schipper and Smith, 1983; Desai and Jain, 1999; Krishnaswami and Subramaniam, 1999). The long-term performance of firms involved in spinoffs is less definitive. Cusatis, Miles, and Woolridge (1993) find evidence of one to three year positive and significant buy-and-hold abnormal returns for 
both the parent and subsidiary firms following a spinoff. McConnell, Ozbilgin, and Wahal (2001) find that the significance of long-term excess returns for parent and subsidiary firms is sensitive to the empirical methodology used and outliers in the data.

A number of theories have been put forth to explain the gains associated with spinoffs, including improved focus and the elimination of negative synergies (Hite and Owers, 1983; Schipper and Smith, 1983; Daley, Mehrotra, and Shivakumar, 1997; Desai and Jain, 1999), improved investment allocation (Gertner, Powers, and Scharfstein, 2002; Ahn and Denis, 2004), transfer of wealth from bondholders to shareholders (Parrino, 1997; Maxwell and Rao, 2003), tax and regulatory advantages (Schipper and Smith, 1983), recontracting benefits after the spinoff (Aron, 1991; Pyo, 2007; Li and Reis, 2009), and reduced information asymmetry (Krishnaswami and Subramaniam, 1999). Management teams are generally perceived as being more efficient following a spin off (Hite and Owers, 1983; Aron, 1991; Seward and Walsh, 1993; Desai and Jain, 1999).

The extant literature examining CEO compensation around spinoffs has focused on pay-for-performance sensitivity for CEOs of parent and subsidiary firms (Pyo, 2007; Li and Reis, 2009). To my knowledge, no study has examined how spinoffs affect other practices that have received attention in the compensation literature. Specifically, relative performance evaluation (RPE), asymmetry in pay for luck, and benchmarking CEO pay have all been widely studied and are still being debated. The primary objective of this paper is to provide additional evidence on these practices by utilizing a sample of firms involved in a spinoff; my analysis will focus on the parent firm. The spinoff event allows the compensation committee to write new contracts - or re-contract in the case where the pre-spinoff parent CEO continues as CEO of the post-spinoff parent- based on the firm 
characteristics of the post-spinoff parent firm. Section 2 explains how firm characteristics that are altered by the spinoff are expected to affect the use of RPE, asymmetry in pay for luck, and benchmarking CEO pay.

Most of the CEOs in the post-spinoff parent firm sample come from the prespinoff firm. Of the 382 post-spinoff firm-year observations, $46 \%$ were previously CEO of the pre-spinoff firm, and $46 \%$ were former employees (non-CEO) of the pre-spinoff firm. Only $2 \%$ of the pre-spinoff CEO sample became CEO of the subsidiary following the spinoff. These numbers are comparable to Denis, Denis, and Walker (2012), who find that $50 \%$ of post-spinoff parent CEOs were pre-spinoff parent CEOs and $33 \%$ were former employees (non-CEO). Denis et al. document that $14 \%$ of their pre-spinoff CEO sample became CEO of the subsidiary. I am focusing my study on the parent firms because they have better coverage in Execucomp and offer a cleaner comparison of preversus post- spinoff firms. ${ }^{1}$

\section{RPE, Asymmetry in Pay for Luck, and Compensation Benchmarking}

Typically, pre-spinoff parent firms have multiple business divisions (Burch and Nanda, 2003; Ahn and Denis, 2004) and high information asymmetry between managers and the market (Krishnaswami and Subramaniam, 1999). Due to the information asymmetry and diversified nature of the pre-spinoff firms, the compensation committee faces at least two challenges when setting CEO compensation. First, as a result of

\footnotetext{
${ }^{1}$ I can also compare compensation practices of pre-spinoff parent firms to post-spinoff subsidiary firms. This comparison is not as relevant though because the post-spinoff subsidiary firm generally cuts ties with the pre-spinoff parent firm. For example, the pre-spinoff parent CEO rarely becomes the post-spinoff subsidiary CEO. The pre-spinoff directors are also more likely to stay with the post-spinoff parent firm (70\%) instead of joining the subsidiary firm (20\%). Denis, Denis, and Walker (2012) provide more details in Tables 3 and 5 .
} 
information asymmetry, share price is a noisy signal of CEO productivity in pre-spinoff firms. The measures of information asymmetry used by Krishnaswami and Subramaniam (1999) are related to dispersion in returns or earnings. The dispersion in these information asymmetry measures is a proxy for the noise in firm returns and share price. As information asymmetry increases, share price contains more noise and becomes less informative about CEO effort. Holmstrom (1979) argues that a signal about CEO effort is useful in constructing an optimal contract, but the usefulness of the signal decreases as the noise of the signal increases.

Second, because they have multiple business divisions (Burch and Nanda, 2003; Ahn and Denis, 2004), pre-spinoff firms may have trouble identifying peer firms. Prespinoff firms that have multiple business divisions in different industries are likely to be exposed to multiple sources of risk that other firms do not experience. Additionally, prior studies find that divisions doing business in industries different than the parent company's industry cause negative synergies in the parent company (Berger and Ofek, 1995). Daley, Mehrotra, and Sivakumar (1997) document that 70\% of their spinoff sample had a subsidiary firm that was in a different industry than the parent firm. ${ }^{2}$ If parent firms with cross-industry subsidiaries are subject to negative synergies, problems in one division can adversely affect other divisions of the company. Trying to make sense of the relation among divisions likely clouds valuation and identification of performance peers for pre-spinoff parent firms.

Following the spinoff, both of these challenges in setting compensation will be reduced for the parent company as both the number of divisions and information

\footnotetext{
${ }^{2}$ In untabulated results, $62 \%$ of the matched parent-subsidiary pairs in my sample are in different industries (2-digit SIC code).
} 
asymmetry are reduced. Further, because of their "clean slate for contracting" nature, spinoffs provide a natural setting in which to examine RPE, asymmetry in pay for skill/luck, and compensation benchmarking. The problems faced in setting compensation for pre-spinoff firms and their (partial) resolution in post-spinoff firms leads to several predictions about how these practices change around spinoffs.

\section{Relative Performance Evaluation (RPE)}

Holmstrom (1982) argues that systematic factors not resulting from CEO actions should be removed when evaluating the CEO. The adjustment provides a better signal of the CEO's performance and protects the CEO's compensation from shocks that are not under her control. RPE occurs when a CEO's performance is evaluated relative to a benchmark that is similarly exposed to and affected by exogenous shocks. Examples of benchmark groups used in RPE include custom peer groups, industry groups, and the overall market.

For example, in 2011, Kraft Foods compensated its CEO as follows: cash (base salary and incentive), benefits and perquisites, and long-term incentives that include restricted stock, non-qualified stock options, and performance shares. The long-term incentive performance shares were granted on a $50 \%$ basis of achieving internal financial metrics (organic revenue growth and operating earnings per share growth) and on a 50\% basis of annualized total shareholder return relative to a performance peer group. The $50 \%$ weight determined by the relative annualized shareholder return is an example of RPE because the CEO will receive more compensation in the form of performance shares if she-Irene Rosenfeld—outperforms her performance benchmark group and less 
compensation if she does not. In this example, the performance peer group was a custom peer group selected by the compensation committee.

Despite its theoretical appeal, RPE has received mixed support empirically (Antle and Smith, 1986; Gibbons and Murphy, 1990; Aggarwal and Samwick, 1999; Garvey and Milbourn, 2003; Rajgopal, Shevlin, and Zamora, 2006; and Albuquerque, 2009, 2014, among others). Part of the problem in documenting RPE is specifying the correct performance benchmark group. Prior to a 2006 SEC ruling, firms did not have to disclose the firms against which they explicitly benchmarked CEO performance and compensation. Thus, prior to 2006 it was impossible to know what benchmark, if any, was explicitly used when evaluating RPE. Recent studies have mitigated this problem by gathering explicit benchmark firms from company filings (Gong, Li, and Shin 2011; DeAngelis and Grinstein 2011) and constructing better performance benchmarks for empirical tests (Albuquerque, 2009; Black, Dikolli, and Hofmann, 2011). Black et al. (2011) find evidence that firms use RPE even if they do not explicitly disclose using RPE in the proxy statement. Their finding is consistent with implicit contracts being important determinants of CEO compensation and validates the use of implicit tests for RPE studies.

In order to use RPE, the compensation committee has to be able to differentiate performance that is attributable to the CEO and performance that is a result of exposure to systematic risk or other factors outside of the CEO's control. Identifying these aspects of performance will allow the CEO to be rewarded/punished for performance attributable to her actions and shielded from performance not under her control. To the extent that these aspects of performance are difficult to measure accurately, implementing RPE 
becomes challenging (Holmstrom and Milgrom, 1987). I argue that pre-spinoff firms have two characteristics that make measuring both the performance attributable to the CEO and performance attributable to exogenous factors difficult.

First, pre-spinoff firms on average have higher information asymmetry between managers and the market than a matched sample of industry-size control firms (Krishnaswami and Subramaniam, 1999). Potential sources of the information asymmetry for the pre-spinoff firm are negative synergies between divisions and unreliable disclosure about the firm because it can manipulate costs, not observable by the market, that are shared among divisions (Krishnaswami and Subramaniam , 1999). The high information asymmetry results in a noisy share price that on average undervalues the firm's underlying assets. ${ }^{3}$

Even for members of the compensation committee, it is difficult to accurately attribute performance as being firm-specific, caused by exposure to multiple sources of exogenous risk (market-wide factors and factors due to exposure to multiple industries), or caused by exposure to negative synergies between divisions within the pre-spinoff firm. For a risk-averse CEO, the noisy share price that is on average under-valuing the firm (as shown by positive abnormal returns on the spinoff announcement) lowers the CEO's incentive to have pay tied to stock performance. ${ }^{4}$ Moral hazard costs associated with information asymmetry can be reduced by RPE because of better risk sharing between the CEO and shareholders (Holmstrom, 1982); however, in the case of pre-

\footnotetext{
${ }^{3}$ Accounting measures can also be used as performance benchmarks. Sloan (1993) argues earnings measures in compensation contracts filter out noise contained in stock prices and can act as a substitute to RPE. However, Gong, Li, and Shin (2011) document $74 \%$ of firms that explicitly state using RPE in their 2006 S\&P 1500 sample used stock returns as the performance metric.

${ }^{4}$ The CEO could have an increased incentive for high pay-for-performance contracts if she knew a spinoff was likely to occur and the contracts would not become valuable until after the spinoff was completed.
} 
spinoff firms, information asymmetry impedes RPE from being used. Thus, agency costs associated with information asymmetry are particularly severe for pre-spinoff firms. Krishnaswami and Subramaniam (1999) find that gains around the announcement of spinoffs are positively related to the degree of information asymmetry, which is consistent with this line of reasoning.

Second, pre-spinoff firms face more difficulty when constructing performance benchmarks. As mentioned above, pre-spinoff firms are potentially exposed to different sources of risk through their multiple divisions. Multi-faceted risk makes finding benchmark firms that are similarly exposed difficult and further inhibits RPE from being used. Following the spinoff, information asymmetry and firm complexity are reduced, allowing compensation committees to better gauge aspects of performance and construct performance benchmarks. In accordance with Holmstrom and Milgrom (1987), RPE should be more widespread when there is less uncertainty regarding the choice of performance benchmark. This reasoning leads to my first hypothesis:

Hypothesis 1: RPE is more prevalent in post-spinoff parent firms than prespinoff parent firms.

The relative lack of RPE in pre-spinoff firms is also consistent with the model of Gopalan, Milbourn, and Song (2010), who argue that if CEOs in multi-divisional firms can change their firms' exposure to sector performance by altering firm strategy, they should be paid for sector performance to incentivize them to choose optimally, even if they have no control over sector performance. Later sections will differentiate my RPE hypothesis based on share price as a noisy signal and the Gopalan et al. hypothesis based on CEOs altering their firms' exposure to exogenous risk. 
Asymmetry in pay for luck

Garvey and Milbourn (2006) document that CEOs are paid for luck asymmetrically-they are rewarded for good luck (which increases compensation) but are not penalized to the same extent for bad luck (which decreases compensation). This finding is widely interpreted as being consistent with the managerial power view of CEO compensation (Frydman and Jenter, 2010). Others, however, find that paying CEOs for luck is not necessarily a result of CEO rent extraction. Bizjak, Lemmon, and Naveen (2008) find no asymmetry in pay for luck for firms that are paid above their peers and that the asymmetry is only found in firms with a CEO who is paid below the peer group median. They argue that CEOs paid below the median peer level receive increases in compensation for retention purposes and find no relation between weaker corporate governance and pay for luck asymmetry.

Oyer (2004) argues that paying for luck can be optimal if the CEO's reservation wage from outside employment opportunities varies with the economy. Rajgopal, Shevlin and Zamora (2006) test Oyer's theory and find supporting evidence of less RPE when the market is up but more RPE when the market is down. More recently, Daniel, Li, and Naveen (2013) find no asymmetry in pay-for-luck practices when using uncorrelated skill and luck measures along with CEO firm-related wealth, which includes existing stock and option holdings, instead of changes (Garvey and Milbourn, 2006) and level (Gopalan, Milbourn, and Song, 2010) of CEO annual pay.

As information asymmetry decreases and performance benchmarks become easier to identify, I expect CEO compensation sensitivity to luck to decrease following a spinoff 
because more systematic factors (i.e., luck) should be removed from CEO compensation. Using the sample of spinoffs, my primary focus in this section is to determine whether asymmetry in CEO compensation sensitivity to good and bad skill/luck is different for pre- and post- spinoff parent firms. To develop the hypotheses about asymmetry in pay for skill/luck, I again rely on the difficulties compensation committees face in setting compensation for the pre-spinoff CEO.

Because of the noise in share price caused by information asymmetry and the difficulty in constructing performance benchmarks for pre-spinoff firms, skill proxies based on stock performance relative to a benchmark are difficult to measure. If the CEO is able to influence pay for skill as a result of this difficulty in measuring skill, then I expect an asymmetry in which CEOs are rewarded for good skill and not punished to the same extent for bad skill. Good skill should be rewarded because the CEO can always argue for RPE if she outperforms benchmarks. If the CEO exhibits bad skill, she will not argue for RPE and instead can argue the bad skill is a result of bad luck or failure of investors to realize the true firm value. This reasoning leads to my second hypothesis:

Hypothesis 2: Pre-spinoff parent CEOs will be rewarded for good skill, but not punished to the same extent for bad skill.

I expect to also see asymmetry in pay for luck where pre-spinoff CEOs are rewarded for good luck and not punished to the same extent for bad luck. Multiple forces are likely to influence this asymmetry. First, due to the noise in share price and difficulty in forming performance benchmarks, the CEO can opportunistically argue that good luck is a result of skill while bad luck is not. Additionally, as stated by Gopalan, Milbourn, and Song (2010), if CEOs of multidivisional pre-spinoff firms sets firm strategy by 
changing firm exposure to sector performance, then the CEOs should optimally be rewarded for sector performance (luck) and punished to a lesser extent given the CEOs have high enough risk aversion. This reasoning leads to my third hypothesis:

Hypothesis 3: Pre-spinoff parent CEOs will be rewarded for good luck, but not punished to the same extent for bad luck.

For post-spinoff firms, I do not expect to see asymmetry in pay for skill or luck. CEOs should still be rewarded for good skill because they are more likely to receive (and can argue for) RPE. However, bad skill should be easier to identify and penalize in postspinoff firms because share price is less noisy and performance benchmarks are easier to identify. Similarly, luck should be easier to identify for post-spinoff firms and should not be rewarded or punished. This reasoning leads to hypotheses 4 and 5:

Hypothesis 4: Post-spinoff parent CEOs will be rewarded for good skill, and equally punished for bad skill.

Hypothesis 5: Post-spinoff parent CEOs will not be rewarded or punished for good or bad luck, respectively.

All of the asymmetry tests may be biased toward finding asymmetry to the extent that measures of luck and skill affect CEO option value. Based on the challenges compensation committees face in setting pre-spinoff CEO compensation, CEOs with relatively large pay-for-performance sensitivities (PPS) have a greater incentive to complete a spinoff. Also, my results in Table 3, and findings from Pyo (2007) suggest that CEO PPS increases following a spinoff. Thus, the spinoff sample may be prone to asymmetry. Given the bias to asymmetry, I use a sample where the pre-spinoff CEO continues as $\mathrm{CEO}$ of the post-spinoff parent firm (I exclude CEOs that continue to the 
subsidiary because of a lack of observations). The matched-CEO sample helps alleviate the asymmetry bias when comparing asymmetry in pay for skill/luck between pre- and post- spinoff CEOs.

\section{Compensation Benchmarking}

Benchmarking CEO pay is the widespread practice of targeting CEO compensation levels at a benchmark representing a group of firms that compete in the same CEO labor pool. Although similar to performance benchmarks, compensation benchmarks are used to determine the appropriate level of compensation, where RPE benchmarks are used to better gauge CEO performance by filtering out common risk factors. Gong, Li, and Shin (2011) report a median $81 \%$ overlap rate (number of common firms in the two benchmark groups divided by number of RPE benchmark firms) between the RPE and compensation benchmark groups. Yet, they still find that the selection of each group reflects different considerations, which is consistent with the notion that the two benchmark groups serve different purposes. Thus, a separate analysis of RPE and compensation benchmarks is warranted.

Proponents of benchmarking CEO pay to a peer group of similar companies claim the practice is used to determine reservation wages for CEOs (Holmstrom and Kaplan, 2003), and empirical studies have shown benchmarking CEO pay to be associated with firm performance, tighter labor markets (Bizjak, Lemmon, and Naveen 2008), and CEO skill (Albuquerque, De Franco, and Verdi, 2013). Opponents of benchmarking CEO pay claim that powerful CEOs opportunistically choose peer companies with highly paid 
CEOs (Bizjak, Lemmon, and Nguyen, 2011; Faulkender and Yang, 2010; Faulkender and Yang, 2013).

The problems identified earlier that compensation committees face when setting compensation for pre-spinoff firms are less likely to affect compensation benchmarking. Noise in firm stock price and difficulty in constructing performance benchmarks do not clearly lead to difficulty in constructing compensation benchmarks. Compensation benchmark firms do not have to be exposed to similar exogenous risk, they only have to hire from the same talent pool.

However, spinoffs affect multiple firm characteristics that can impact compensation benchmarking. Post-spinoff firms are smaller (measured by revenue) and less complex because they divest a business division. CEOs of larger companies typically receive higher compensation that CEOs of smaller companies (Gabaix and Landier, 2008). This reasoning suggests that post-spinoff CEOs will receive less compensation on average than pre-spinoff CEOs. However, the model by Gabaix and Landier predicts that managerial talent drives the difference in salaries between small and large companies. With spinoffs, it is difficult to argue that the post-spinoff CEOs are more or less talented than the pre-spinoff CEOs (especially when the pre-spinoff CEO becomes the postspinoff CEO). So on average, even though firm size decreases following the spinoff, I would not necessarily expect CEO compensation to decrease because CEO talent does not necessarily decrease.

Because CEO talent does not decrease following the spinoff, post-spinoff firms likely hire from the same talent pool as they did when they were pre-spinoff. If so, then the compensation benchmark group used by both pre- and post- spinoff firms will be 
similar. When testing for compensation benchmarking, this similarity means that postspinoff firms will appear to be benchmarking to larger firms with higher compensated CEOs than their industry-size peers. This reasoning leads to my next hypothesis:

Hypothesis 6: Post-spinoff parent CEOs will receive higher increases in compensation due to benchmarking than pre-spinoff CEOs.

\section{Data and sample selection}

\section{Data selection}

I start by using SDC to identify firms that complete a spinoff between 1992 and 2012 and also distribute at least $80 \%$ of the shares of the subsidiary. The $80 \%$ requirement identifies tax-free spinoffs. About 60 spinoffs from the SDC sample have the same company listed as a parent and subsidiary. For these spinoffs, I look at the synopsis in SDC to determine the actual parent and subsidiary companies and look up the correct identifiers for those firms. Next, I match the spinoff firms with available CUSIP identifiers to CRSP and Compustat. Of the 557 spinoffs identified in SDC, I match 315 of the parent firms (the pre- and post- spinoff firm share the same identifier). I hand check firms that matched to more than one PERMNO identifier in CRSP and selected the most appropriate PERMNO based on company name and available date range.

The final step is to collect firm-year data. I collect return data from CRSP, financial data from Compustat, and compensation data from Execucomp. I match firmyear observations if the fiscal year end occurred within three years before, or four years after the spinoff, and exclude observations with a fiscal year during which the spinoff occurred. I exclude these observations to better identify pre- and post- spinoff 
observations. For example, if a spinoff occurred one week before the fiscal year end, the classification scheme would label that observation as post-spinoff, even though the firm was pre-spinoff for the majority of the fiscal year. Because I exclude the fiscal year during which the spinoff occurred, I match post-spinoff firm-year observations over four years (instead of three) to better balance the pre- and post- spinoff firm-year observations. For a given firm, I also require the number of pre-spinoff observations to be equal to the number of post-spinoff observations. The final sample has slightly more post-spinoff observations due to the deletions caused by overlapping firm-year windows described below.

Some firms in the sample conducted more than one spinoff. To deal with potential offsetting effects from overlapping firm-year windows, I excluded 134 firm-year observations for being in both the pre- and post- spinoff parent sample. I allowed duplicate firm-year observations if they are all post-spinoff parent observations or all prespinoff parent observations. Allowing these duplicates gives more weight to firm-year observations of companies that completed multiple spinoffs if they did so within a relatively short time period. As shown in Panel B of Table 1, 83\% of the sample firmyear observations have no duplicates. Table 1, Panel C shows the final sample is weighted more towards the beginning of the sample period during the 1990s and early 2000s. The most active year for spinoffs in the sample is 1996, with 28 spinoffs, and the least active spinoff year is 2004 , with seven spinoffs.

\section{Data characteristics}


Table 2 contains summary statistics for the sample. Naturally, pre-spinoff firms (Panel A) are larger (as measured by revenue) than post-spinoff firms (Panel B). Despite being smaller, the post-spinoff parent firms have an almost identical median total compensation level ( $\$ 3.79$ million) relative to their pre-spinoff counterparts $(\$ 3.72$ million). Other notable differences between pre-and post- spinoff parent firms include post-spinoff parents having higher variance (both total return and idiosyncratic) and higher book-to-market ratios. Breaking down total CEO compensation into its main components, post-spinoff parent CEOs receive a lower salary and bonus, but higher stock grants. Panels $\mathrm{C}$ and $\mathrm{D}$ of Table 2 use a sample that includes firm-year observations only if the pre-spinoff CEO is the same as the post-spinoff CEO. This specification helps alleviate fears that differences in variables across the spinoff subsamples are driven by CEO characteristics.

\section{Empirical tests and results}

\section{RPE tests and results}

My sample contains 36 firms that completed a spinoff after the 2006 SEC disclosure ruling. For those 36 firms, I collected information on explicit RPE use from the firms' proxy statements for the year directly before and after the spinoff using the methodology described by Gong, Li, and Shin (2011). Six of the 36 firms went from being non-RPE firms before the spinoff to RPE firms after the spinoff, ten firms were RPE users before and after the spinoff, and 20 firms were non-RPE users before and after the spinoff. While this subsample is small, the fact that $23 \%$ ( 6 of 26 ) of the non-RPE firms prior to the spinoff became RPE firms following the spinoff and zero firms went 
from being RPE to non-RPE firms provides anecdotal evidence supporting an increase in RPE use following a spinoff.

In order to utilize the full spinoff sample in the empirical tests, I use a methodology similar to Albuquerque (2009), who uses the following specification:

$$
\text { CEOPay }_{i t}=\mathrm{a}_{0}+\mathrm{a}_{1} \text { FirmPerf }_{\mathrm{it}}+\mathrm{a}_{2} \text { BenchPerf }_{\mathrm{it}}+\mathrm{a}_{3} \text { ControlVariables }_{\mathrm{it}}+\mathrm{e}_{\mathrm{it}}
$$

Subscript $t$ indicates the year and subscript $\mathrm{i}$ indicates the firm-benchmark pair. $\mathrm{CEOPay}_{\text {it }}$ is the compensation of the CEO, measure as both the log of total compensation and the change in log compensation. FirmPerf ${ }_{i t}$ and BenchPerf $f_{i t}$ are performance measures for the firm-benchmark pair i. I use stock returns to measure the performance variables and industry-size benchmark groups. Control variables account for factors affecting CEO compensation not related to firm or benchmark performance. Appendix A contains variable definitions.

Table 2, Panels E through G, provide evidence on the most appropriate benchmark group. The performance benchmark used for RPE should have similar exposure to exogenous shocks as the spinoff firm. Panels E (pre-spinoff) and F (postspinoff) show the correlation among the spinoff firm fiscal-year returns and potential benchmark returns over the same period. The industry-size benchmark has the highest correlation to the spinoff firm stock returns for both the pre- and post- spinoff sample. Panel G shows the pre- and post- spinoff results of regressing the spinoff firm fiscal-year returns on a potential benchmark return and year fixed effects (fixed effects output omitted). The regression specification with the industry-size benchmark group has the highest adjusted R-squared value for both the pre- and post- spinoff sample. 
DeAngelis and Grinstein (2011) document that 34\% of S\&P 500 firms claim to use RPE in 2007. Of those firms claiming to use RPE, 39\% benchmark against either a market-wide or industry-wide index and $61 \%$ benchmark against a "home-made" peer group, providing support for the industry-size benchmark used by Albuquerque (2009). The results from Table 2 and evidence from prior studies supports the use of the industrysize benchmark.

Table 3 has the results of Equation (1) using indicator interaction terms for preand post- spinoff with firm and benchmark returns. Panel A uses the log of total compensation as the dependent variable and Panel B uses change in log compensation as the dependent variable. In Panel B, log revenue and book-to-market are also defined as changes in those variables. The results in Table 3, Panel A, indicate that, ceteris paribus, a firm's stock return is not significantly related to total compensation for pre-spinoff observations. Furthermore, the coefficient for the pre-spinoff peer return is positive and significant.

For post-spinoff firms, the coefficient on firm stock return increases in magnitude and significance compared to the pre-spinoff sample. Also, the peer return has a negative coefficient for the post-spinoff sample (although not statistically significant). The results suggest RPE is more prevalent in post-spinoff firms than pre-spinoff firms, supportive of Hypothesis 1.

The rows at the bottom of Tables 3 and 4 have p-values for the RPE test of:

Firm stock return $*$ spinoff indicator + Peer return* spinoff indicator $=0$. In the pre-spinoff test, the p-value is 0.04 , rejecting the use of RPE. The post-spinoff test does not reject the use of RPE with a p-value of 0.91. The RPE test results from Panel B 
offer the same conclusions as Panel A. Additionally, Table 3 reports the differences in the pre- and post- spinoff coefficients for the firm stock return and peer return. Compared to pre-spinoff CEOs, post-spinoff CEOs have compensation that is more sensitive to firm performance (significant near the $10 \%$ level), and less sensitive to exogenous shocks as measured by industry-size returns (significant at the 5\% level).

One concern when examining RPE is difference in CEO ability. Oyer (2004) argues that an absence of RPE is optimal for talented CEOs because the CEO's reservation wages from outside employment varies with the economy. To alleviate this concern, the regressions in Table 4 use a sample in which every CEO in the pre-spinoff sample is also in the post-spinoff sample.

The results in Table 4 are not as supportive of Hypothesis 1 as those in Table 3. None of the coefficients dealing with firm or benchmark returns is statistically significant. The tests at the bottom of the table are not informative in light of the weak significance of the variables of interest.

Overall, the tests in Table 3 show that CEO compensation is more sensitive to peer performance than firm performance for pre-spinoff firms. Following the spinoff, the sensitivity of compensation to firm performance increases and the sensitivity of compensation to peer performance decreases and becomes negative (although not statistically significant). These results are consistent with Hypothesis 1-RPE is used more in firms following a spinoff than for pre-spinoff firms. The tests in Table 4 using a matched CEO sample are not as supportive of Hypothesis 1.

Recall that RPE practices could change following the spinoff for two reasons: share price noise could be reduced and benchmark firms could be easier to identify 
following the spinoff. The descriptive statistics in Table 2, Panels A through D, show that idiosyncratic variance, the main measure of share price noise, increases for the postspinoff parent sample. This finding contradicts Krishnaswami and Subramaniam (1999), who find that idiosyncratic variance decreases for their post-spinoff parent sample. Table 2, Panels E through G, indicate that the post-spinoff parent returns are more closely associated with the benchmark return than the pre-spinoff parent returns. These findings suggest that the increase in RPE use for post-spinoff firms documented in Table 3 are due to benchmark firms being easier to identify following the spinoff and not due to a decrease in share price noise.

Asymmetry in pay for luck tests and results

To measure skill and luck, I follow Carhart (1997) and regress daily excess firm stock returns on the daily Fama-French and momentum factors over the fiscal year during which the compensation occurs. To account for nonsynchronous trading, I also include one lag return for each factor, following Lewellen and Nagel (2006). The regression model is

$r_{i, t}=\propto_{i}+\beta_{i, 0} r_{m, t}+\beta_{i, 1} r_{m, t-1}+\beta_{i, 2} r_{s m b, t}+\beta_{i, 3} r_{s m b, t-1}+\beta_{i, 4} r_{h m l, t}+\beta_{i, 5} r_{h m l, t-1}+\beta_{i, 6} r_{m o m, t}+\beta_{i, 7} r_{m o m, t-1}$

where $r_{i, t}$ is the excess return on stock i, $r_{m, t}$ is the excess market return, $r_{s m b, t}$ is the return on the 'small minus big' portfolio, $r_{h m l, t}$ is the return on the 'high minus low' portfolio, and $r_{m o m, t}$ is the return on momentum portfolio on day t. ${ }^{5}$ The intercept (alpha) is the measure of skill, and the average excess return over the year minus the intercept is

\footnotetext{
5 All factor returns were obtained from Kenneth French's data library, http://mba.tuck.dartmouth.edu/pages/faculty/ken.french/data_library.html
} 
the measure of luck. Multiplying by 250 annualizes both skill and luck. These measures of skill and luck are widely used in the mutual fund literature and also used by Daniel, Li, and Naveen (2013) in their study of asymmetry in pay for luck. ${ }^{6}$ The correlation between skill and luck is 0.03 . The indicator variables bad skill and bad luck take values of one when skill and luck are less than zero.

The results in Table 5, Panel A, show that pre-spinoff firms do not reward CEOs for either skill or luck. However, the coefficient of skill increases and becomes statistically significant for post-spinoff firms while the luck coefficient remains insignificant. The coefficients of the skill and luck variables in Panel B, where the dependent variable is change in log compensation, are not statistically significant for the pre-spinoff observations. The luck coefficient becomes positive and significant (5\% level) for the post-spinoff sample in Panel B. The bottom of the table compares pre- and post- spinoff skill and luck coefficients. In Panel A, compensation is more sensitive to skill (significant near the $10 \%$ level) for post-spinoff firms.

When using the matched CEO sample in Table 6, the skill and luck coefficients are again statistically insignificant for Panel A while the luck coefficient is positive and significant (10\% level) for post-spinoff firms in Panel B. The results in Tables 5 and 6 offer mixed support for Hypothesis 1.

Tables 7 and 8 examine if skill and luck are rewarded asymmetrically. Table 7 , Panel A shows good luck is rewarded for both pre- and post- spinoff firms. The luck * bad luck coefficient is negative and significant for post-spinoff firms and is larger in

\footnotetext{
${ }^{6}$ These measures are not common for measuring skill and luck in the compensation literature. I use them because they only require data available at the time compensation is set (end of fiscal year), and I do not have to run an annual pooled regression that includes pre- and post- spinoff observations for the same firm.
} 
magnitude than the luck coefficient; during periods of bad luck (luck <0), compensation increases as luck becomes more negative for post-spinoff firms. Table 7, Panel B does not display the same asymmetry in pay for luck for post-spinoff firms. The pre- and postspinoff coefficients on the skill and luck variables are not significantly different. Table 8 uses the sample of matched CEOs. Both panels show post-spinoff CEOs are rewarded for good luck and not punished for bad luck. The bottom of Table 8 shows that post-spinoff firms reward CEOs more for good luck (Panel B) and reward them less for good skill (Panel A) than pre-spinoff firms. The results in Tables 7 and 8 do not support Hypotheses 2 through 5. Instead, the main result from the tables suggests that post-spinoff CEOs are rewarded asymmetrically for luck while pre-spinoff CEOs are not.

\section{Compensation benchmarking tests and results}

To construct the compensation peer groups, I create five size groups from all firms in Execucomp according to prior year market cap for each year and industry (FamaFrench 12 industries). ${ }^{7}$ I define the variable compensation distance each year as the prior year's median compensation level from the industry-size group minus the compensation level of the firm in the same industry-size group. Thus, CEOs with a positive compensation distance are paid below the median of the industry-size peer group in the prior year. The low compensation indicator variable takes a value of one if compensation distance is positive and zero otherwise.

\footnotetext{
${ }^{7}$ I use five size groups because I am using 12 industry groups. Prior studies commonly use two size groups but have more industry definitions (SIC 2-digit or Fama-French 48 industries). My goal in using five size groups is to have the number of firms in the industry-size benchmark compensation groups be comparable to previous studies.
} 
The CDF compensation distance variable is the cumulative distribution function (CDF) of the compensation distance variable calculated each year for the industry-size groups. If firms are benchmarking CEO compensation to median industry-size levels, the coefficients on the low compensation indicator variable and the CDF compensation distance will be positively related to compensation. I follow Cremers and Grinstein (2014) and use change in log compensation as the dependent variable and also account for lagged compensation because of the positive autocorrelation of CEO compensation across time.

The results in Table 9 use the low compensation indicator and show significant use of benchmarking in both pre- and post- spinoff firms. Post-spinoff parent firms show the largest increases in compensation following a year of being below peer median compensation when looking at the full sample in Panel A. In the matched CEO sample in Panel B, pre-spinoff firms show more compensation benchmarking than post-spinoff firms. Table 10 shows significant compensation benchmarking when using the CDF of compensation distance for both pre- and post- spinoff firms. None of the differences at the bottom of Tables 9 and 10 between pre- and post- spinoff benchmarking variables is significant. The results in these tables do not support Hypothesis 6.

\section{Robustness}

To address the concern that the results of the spinoff firms are being driven by factors other than the spinoff event, I construct and re-run the empirics on a matched sample on non-spinoff firms. To construct the matched sample, I first take the 161 firms in my spinoff sample and match them to non-spinoff firms in the same industry (Fama- 
French 12) with the same fiscal year end. The matched firms must have financial and return data that at least spans the years during which the spinoff firm is included in the original sample. After meeting these requirements, I choose the matched firm that is closest in size (based on revenue) to the spinoff firm at the fiscal year end during which the spinoff occurs. ${ }^{8}$

Next, I calculate the variables required to run the empirical tests for the matched firms over a three-year window around the spinoff year. I then match the firm-year observations of the matched sample to the firm-year observations of the spinoff sample. The final matched sample has 675 firm-year observations, which is fewer than the 729 firm-year observations in the spinoff sample. This decrease is a result of missing data in the matched sample.

Table 11 shows descriptive statistics for the matched firms. Compared to the spinoff firms in Table 2 (Panels A and B), the matched firms seem to be similar with respect to log total compensation, firm size (measured by log revenue) and book-tomarket. As expected, the matched firms for the post-spinoff observations are slightly larger than their spinoff sample counterparts because the matched sample firms do not divest a part of their company. Overall, the firm characteristics are similar between the spinoff sample and matched sample.

Table 12 provides the results of the RPE tests for the matched sample. Unlike the spinoff sample results in Table 3 (Panels A and B), the matched sample firms do not appear to alter their RPE use between the pre- and post- spinoff timeframe. The matched

\footnotetext{
8 I also used a two-step matching process of matching on size and book-to-market. This process cut the number of matched firms I was able to produce so I favor matching on size alone. However, the empirical results from the two-step matching process are qualitatively similar to the results of the size-matched sample.
} 
firms actually see a decrease in pay for performance sensitivity (PPS) in the post-spinoff period where the CEO's compensation becomes less sensitive to the firm's stock return. This decrease in PPS sharply contrasts with the results in Table 3 where the CEO's compensation becomes more sensitive to stock performance and less sensitive to industry-size performance following the spinoff. The industry-size return does not significantly affect the matched CEO's compensation in either the pre- or post- spinoff period. These results indicate that the relationship between CEO compensation and firm performance along with industry-size performance is unique to the sample of spinoff firms.

\section{Conclusions}

This study examines the use of relative performance evaluation (RPE), asymmetric pay for luck, and compensation benchmarking for a sample of firms that have completed a spinoff. These compensation practices have been debated in the academic literature and in the popular press. Spinoffs allow for a unique setting in which to examine these practices because spinoffs affect firm characteristics that impact the use of these practices. By examining how these compensation practices differ before and after the spinoff, we gain new insight on the practices.

The results show that pre-spinoff firms do not use RPE. Pre-spinoff CEO compensation is significantly related to the performance of an industry-size peer group and not related to firm performance. Following the spinoff, the same set of firms use RPE, and CEO compensation is more closely tied to firm performance and shielded from industry-size performance. A possible explanation for the increased use of RPE in the 
post-spinoff sample is that performance peer groups are easier to identify following the spinoff. The descriptive statistics show that firm returns are more closely associated with the industry-size peer returns in the post-spinoff sample than the pre-spinoff sample. Another possibility is that decreases in information asymmetry contribute to the increase in RPE for post-spinoff firms. However, in contrast to Krishnaswami and Subramaniam (1999), I find that information asymmetry (measured by idiosyncratic variance) increases following the spinoff. These results are also robust to alternative explanations such as time effects influencing the relation between CEO compensation and firm/benchmark performance.

Pre-spinoff CEO compensation is not significantly affected by good or bad skill/luck. Post-spinoff CEOs are rewarded for good luck and not punished for bad luck. This result is robust to a sample of firms where the pre-spinoff CEO continued on to be the post-spinoff CEO. Given the findings on RPE, this result is puzzling. If RPE use increases for post-spinoff firms, then it is reasonable to expect that CEO compensation is less affected by exogenous forces (luck) and more affected by skill. Future work is needed to clarify the relation between RPE and asymmetry in pay for skill/luck.

The last set of empirical tests show significant use of compensation benchmarking for both pre- and post- spinoff firms. However, the amount of benchmarking is not significantly different between the two groups. The paper's main result provides evidence that difficulty in forming a performance benchmark inhibits the use of RPE. I also document changes in asymmetrical pay for luck between pre- and post- spinoff firms but more work is needed to better understand these results and how they relate to RPE. 


\section{Table 1 - Sample Selection}

Panel A contains information on the sample construction. Panel B lists the number of duplicate observations in the sample as a result of overlapping firm-year windows around the spinoff. Panel C shows the distribution of CRSP-matched spinoffs in the sample by the year the spinoff was completed.

Panel A

Spinoffs identified in SDC with effective date between 1992 and 2012

that have completed spinoff with at least $80 \%$ shares acquired

Parent companies (pre- and post- spinoff) in CRSP/Compustat

Parent firm-year observations with fiscal year end less than 3 years before spinoff in CRSP/Compustat/Execucomp

Parent firm-year observations with fiscal year end less than 4 years after spinoff in CRSP/Compustat/Execucomp *

* The fiscal year in which the spinoff occurred is omitted

Panel B

\begin{tabular}{r|rr|r}
\hline $\begin{array}{r}\text { Duplicate } \\
\text { Observations }\end{array}$ & & & $\begin{array}{r}\text { Total firm-year } \\
\text { observations }\end{array}$ \\
\hline 0 & 299 & 308 & 607 \\
1 & 19 & 24 & 86 \\
2 & 2 & 2 & 12 \\
3 & 1 & 5 & 24 \\
\hline $\begin{array}{l}\text { Total firm-year } \\
\text { observations }\end{array}$ & 347 & 382 & 729
\end{tabular}

\begin{tabular}{|c|c|c|c|c|c|c|c|c|c|}
\hline \multicolumn{10}{|l|}{ Panel C } \\
\hline Year & Frequency & Percent & $\begin{array}{l}\text { Cumulative } \\
\text { Frequency }\end{array}$ & $\begin{array}{r}\text { Cumulative } \\
\text { Percent }\end{array}$ & Year & Frequency & Percent & $\begin{array}{l}\text { Cumulative } \\
\text { Frequency }\end{array}$ & $\begin{array}{r}\text { Cumulative } \\
\text { Percent }\end{array}$ \\
\hline 1992 & 11 & 3.49 & 11 & 3.49 & 2003 & 10 & 3.17 & 212 & 67.3 \\
\hline 1993 & 19 & 6.03 & 30 & 9.52 & 2004 & 7 & 2.22 & 219 & 69.52 \\
\hline 1994 & 17 & 5.4 & 47 & 14.92 & 2005 & 9 & 2.86 & 228 & 72.38 \\
\hline 1995 & 19 & 6.03 & 66 & 20.95 & 2006 & 8 & 2.54 & 236 & 74.92 \\
\hline 1996 & 28 & 8.89 & 94 & 29.84 & 2007 & 16 & 5.08 & 252 & 80 \\
\hline 1997 & 24 & 7.62 & 118 & 37.46 & 2008 & 15 & 4.76 & 267 & 84.76 \\
\hline 1998 & 15 & 4.76 & 133 & 42.22 & 2009 & 11 & 3.49 & 278 & 88.25 \\
\hline 1999 & 18 & 5.71 & 151 & 47.94 & 2010 & 12 & 3.81 & 290 & 92.06 \\
\hline 2000 & 22 & 6.98 & 173 & 54.92 & 2011 & 12 & 3.81 & 302 & 95.87 \\
\hline 2001 & 19 & 6.03 & 192 & 60.95 & 2012 & 13 & 4.13 & 315 & 100 \\
\hline 2002 & 10 & 3.17 & 202 & 64.13 & & & & & \\
\hline
\end{tabular}




\section{Table 2 - Descriptive Statistics}

Panel A provides summary statistics on the pre-spinoff parent sample. Panel B details postspinoff parent firms. Panels C and D provide summary statistics for pre- and post- spinoff firms for which I was able to confirm that the last CEO of the pre-spinoff firm stayed as CEO of the post-spinoff parent firm; for these tables, the CEO in the pre-spinoff firm sample is also in the post-spinoff parent firm sample. Panels E and F are correlation matrices of the fiscal year return variables for pre- and post- spinoff observation respectively. Panel G shows selected results of regressing the firm stock return over the fiscal year on different benchmark returns and year fixed effects. Compensation data are denominated in thousands of constant 1992 dollars. Financial data are denominated in millions of constant 1992 dollars. Variable definitions are in Appendix A.

\begin{tabular}{|c|c|c|c|c|c|c|}
\hline \multirow[b]{2}{*}{ Variable } & \multirow[b]{2}{*}{$\mathrm{N}$} & \multirow[b]{2}{*}{ Mean } & \multirow[b]{2}{*}{ Median } & \multirow[b]{2}{*}{ Std dev } & \multicolumn{2}{|c|}{$\begin{array}{l}\text { Test statistic for pre- versus post- } \\
\text { spinoff differences in the }\end{array}$} \\
\hline & & & & & Mean (p-value) & Median (p-value) \\
\hline Log total compensation & 347 & 8.18 & 8.22 & 1.23 & 0.66 & 0.74 \\
\hline Firm stock return & 347 & 0.14 & 0.10 & 0.47 & 0.12 & 0.28 \\
\hline Peer return (industry-size) & 347 & 0.13 & 0.13 & 0.27 & 0.32 & 0.32 \\
\hline Peer return (industry) & 347 & 0.17 & 0.14 & 0.33 & 0.89 & 0.25 \\
\hline S\&P 500 return & 347 & 0.10 & 0.12 & 0.17 & 0.00 & 0.94 \\
\hline Luck & 347 & 13.05 & 14.17 & 27.20 & 0.86 & 0.48 \\
\hline Skill & 347 & -2.81 & -1.34 & 29.10 & 0.03 & 0.13 \\
\hline Bad luck & 347 & 0.24 & 0 & 0.43 & 0.23 & 0.23 \\
\hline Bad skill & 347 & 0.52 & 1.00 & 0.50 & 0.17 & 0.17 \\
\hline Compensation distance & 274 & -2260.81 & -247.80 & $6,752.64$ & 0.95 & 0.65 \\
\hline Low compensation indicator & 274 & 0.40 & 0 & 0.49 & 0.51 & 0.51 \\
\hline CDF compensation distance & 274 & 0.47 & 0.45 & 0.27 & 0.56 & 0.43 \\
\hline Market beta & 347 & 0.34 & 0.32 & 0.76 & 0.01 & 0.11 \\
\hline Return variance & 347 & 7.12 & 3.47 & 10.43 & 0 & 0 \\
\hline Idiosyncratic Variance & 347 & 1.85 & 1.54 & 1.17 & 0.00 & 0.00 \\
\hline Log revenue & 347 & 8.25 & 8.18 & 1.51 & 0.01 & 0.01 \\
\hline Book-to-Market & 347 & 0.54 & 0.41 & 0.57 & 0.00 & 0.04 \\
\hline Regulation & 347 & 0.04 & 0 & 0.19 & 0.95 & 0.95 \\
\hline Interlock & 347 & 0.08 & 0 & 0.27 & 0.00 & 0.00 \\
\hline Tenure & 347 & 7.49 & 7.62 & 0.95 & 0 & 0 \\
\hline Herfindahl & 347 & 0.04 & 0.03 & 0.04 & 0.35 & 0.01 \\
\hline Divisions & 347 & 6.53 & 6.00 & 3.80 & 0.97 & 0.82 \\
\hline Total compensation & 347 & $7,106.38$ & $3,719.52$ & $10,763.49$ & 0.03 & 0.74 \\
\hline Salary & 347 & 697.38 & 648.13 & 392.57 & 0.02 & 0.15 \\
\hline Bonus & 347 & 930.64 & 462.30 & $1,550.49$ & 0.01 & 0.01 \\
\hline Other compensation & 347 & 251.00 & 86.61 & 587.85 & 0.17 & 0.97 \\
\hline Stock grants & 347 & 706.47 & 0 & $1,639.16$ & 0.02 & 0.01 \\
\hline Option awards & 347 & $3,765.32$ & $1,006.26$ & $9,560.92$ & 0.01 & 0.85 \\
\hline
\end{tabular}


Panel B: Post-spinoff parent firms

Test statistic for pre- versus post-

spinoff differences in the

\begin{tabular}{|c|c|c|c|c|c|c|}
\hline \multirow[b]{2}{*}{ Variable } & \multirow[b]{2}{*}{$\mathrm{N}$} & \multirow[b]{2}{*}{ Mean } & \multirow[b]{2}{*}{ Median } & \multirow[b]{2}{*}{ Std dev } & \\
\hline & & & & & Mean (p-value) & Median (p-value) \\
\hline Log total compensation & 382 & 8.14 & 8.24 & 1.02 & 0.66 & 0.74 \\
\hline Firm stock return & 382 & 0.21 & 0.13 & 0.66 & 0.12 & 0.28 \\
\hline Peer return (industry-size) & 382 & 0.11 & 0.10 & 0.29 & 0.32 & 0.32 \\
\hline Peer return (industry) & 382 & 0.17 & 0.11 & 0.39 & 0.89 & 0.25 \\
\hline S\&P 500 return & 382 & 0.06 & 0.13 & 0.20 & 0.00 & 0.94 \\
\hline Luck & 382 & 12.67 & 12.40 & 30.51 & 0.86 & 0.48 \\
\hline Skill & 382 & 2.45 & 1.87 & 35.39 & 0.03 & 0.13 \\
\hline Bad luck & 382 & 0.28 & 0 & 0.45 & 0.23 & 0.23 \\
\hline Bad skill & 382 & 0.47 & 0 & 0.50 & 0.17 & 0.17 \\
\hline Compensation distance & 311 & -2222.33 & -199.37 & $6,986.30$ & 0.95 & 0.65 \\
\hline Low compensation indicator & 311 & 0.42 & 0 & 0.50 & 0.51 & 0.51 \\
\hline CDF compensation distance & 311 & 0.48 & 0.48 & 0.27 & 0.56 & 0.43 \\
\hline Market beta & 382 & 0.18 & 0.21 & 0.82 & 0.01 & 0.11 \\
\hline Return variance & 382 & 10.21 & 5.53 & 14.84 & 0.00 & 0 \\
\hline Idiosyncratic Variance & 382 & 2.12 & 1.81 & 1.35 & 0.00 & 0.00 \\
\hline Log revenue & 382 & 7.96 & 7.91 & 1.52 & 0.01 & 0.01 \\
\hline Book-to-Market & 382 & 0.70 & 0.48 & 0.78 & 0.00 & 0.04 \\
\hline Regulation & 382 & 0.04 & 0 & 0.19 & 0.95 & 0.95 \\
\hline Interlock & 382 & 0.03 & 0 & 0.18 & 0.00 & 0.00 \\
\hline Tenure & 382 & 7.09 & 7.00 & 0.89 & 0 & 0 \\
\hline Herfindahl & 382 & 0.04 & 0.03 & 0.04 & 0.35 & 0.01 \\
\hline Total compensation & 382 & $5,589.70$ & $3,793.85$ & $6,880.79$ & 0.03 & 0.74 \\
\hline Salary & 382 & 638.07 & 621.77 & 290.35 & 0.02 & 0.15 \\
\hline Bonus & 382 & 657.86 & 314.29 & $1,143.41$ & 0.01 & 0.01 \\
\hline Other compensation & 382 & 318.88 & 90.13 & 728.76 & 0.17 & 0.97 \\
\hline Stock grants & 382 & $1,002.93$ & 0 & $1,796.90$ & 0.02 & 0.01 \\
\hline Option awards & 382 & $2,251.88$ & $1,019.54$ & $4,666.75$ & 0.01 & 0.85 \\
\hline
\end{tabular}


Panel C: Pre-spinoff parent firms with matched CEO

\begin{tabular}{|c|c|c|c|c|c|c|}
\hline \multirow[b]{2}{*}{ Variable } & \multirow[b]{2}{*}{$\mathrm{N}$} & \multirow[b]{2}{*}{ Mean } & \multirow[b]{2}{*}{ Median } & \multirow[b]{2}{*}{ Std dev } & \multicolumn{2}{|c|}{$\begin{array}{l}\text { Test statistic for pre- versus post- } \\
\text { spinoff differences in the }\end{array}$} \\
\hline & & & & & Mean (p-value) & Median (p-value) \\
\hline Log total compensation & 218 & 8.27 & 8.25 & 1.11 & 0.60 & 0.16 \\
\hline Firm stock return & 218 & 0.13 & 0.09 & 0.41 & 0.35 & 0.31 \\
\hline Peer return (industry-size) & 218 & 0.13 & 0.12 & 0.28 & 0.59 & 0.84 \\
\hline Peer return (industry) & 218 & 0.18 & 0.15 & 0.34 & 0.75 & 0.54 \\
\hline S\&P 500 return & 218 & 0.11 & 0.13 & 0.17 & 0.14 & 0.92 \\
\hline Luck & 218 & 12.30 & 13.65 & 28.34 & 0.85 & 1.00 \\
\hline Skill & 218 & -2.71 & -2.11 & 24.45 & 0.05 & 0.11 \\
\hline Bad luck & 218 & 0.25 & 0 & 0.43 & 0.94 & 0.94 \\
\hline Bad skill & 218 & 0.54 & 1.00 & 0.50 & 0.13 & 0.13 \\
\hline Compensation distance & 163 & -1956.79 & -208.46 & $6,463.08$ & 0.81 & 0.74 \\
\hline Low compensation indicator & 163 & 0.42 & 0 & 0.50 & 0.78 & 0.78 \\
\hline CDF compensation distance & 163 & 0.46 & 0.46 & 0.28 & 0.50 & 0.59 \\
\hline Market beta & 218 & 0.33 & 0.24 & 0.76 & 0.02 & 0.11 \\
\hline Return variance & 218 & 6.23 & 3.23 & 7.94 & 0.13 & 0.03 \\
\hline Idiosyncratic Variance & 218 & 1.79 & 1.57 & 0.91 & 0.71 & 0.31 \\
\hline Log revenue & 218 & 8.21 & 8.19 & 1.45 & 0.14 & 0.02 \\
\hline Book-to-Market & 218 & 0.50 & 0.41 & 0.35 & 0.26 & 0.84 \\
\hline Regulation & 218 & 0.02 & 0 & 0.14 & 0.52 & 0.51 \\
\hline Interlock & 218 & 0.09 & 0 & 0.28 & 0.24 & 0.25 \\
\hline Tenure & 218 & 7.37 & 7.49 & 1.00 & 0 & 0.16 \\
\hline Herfindahl & 218 & 0.04 & 0.03 & 0.04 & 0.93 & 0.06 \\
\hline Divisions & 218 & 6.59 & 6.00 & 4.05 & 0.26 & 0.42 \\
\hline Total compensation & 218 & $7,414.50$ & $3,807.00$ & $11,725.53$ & 0.15 & 0.16 \\
\hline Salary & 218 & 708.55 & 661.45 & 367.09 & 0.08 & 1.00 \\
\hline Bonus & 218 & 851.97 & 551.29 & $1,294.79$ & 0.02 & 0.02 \\
\hline Other compensation & 218 & 276.73 & 98.27 & 634.58 & 0.49 & 0.69 \\
\hline Stock grants & 218 & 672.82 & 0 & $1,588.01$ & 0.02 & 0.48 \\
\hline Option awards & 218 & $4,278.86$ & $1,128.94$ & $10,903.13$ & 0.01 & 1.00 \\
\hline
\end{tabular}




\begin{tabular}{|c|c|c|c|c|c|c|}
\hline \multirow[b]{2}{*}{ Variable } & \multirow[b]{2}{*}{$\mathrm{N}$} & \multirow[b]{2}{*}{ Mean } & \multirow[b]{2}{*}{ Median } & \multirow[b]{2}{*}{ Std dev } & \multicolumn{2}{|c|}{$\begin{array}{l}\text { Test statistic for pre- versus post- } \\
\text { spinoff differences in the }\end{array}$} \\
\hline & & & & & Mean (p-value) & Median (p-value) \\
\hline Log total compensation & 176 & 8.21 & 8.38 & 1.09 & 0.60 & 0.16 \\
\hline Firm stock return & 176 & 0.18 & 0.13 & 0.51 & 0.35 & 0.31 \\
\hline Peer return (industry-size) & 176 & 0.12 & 0.12 & 0.30 & 0.59 & 0.84 \\
\hline Peer return (industry) & 176 & 0.17 & 0.14 & 0.38 & 0.75 & 0.54 \\
\hline S\&P 500 return & 176 & 0.08 & 0.13 & 0.19 & 0.14 & 0.92 \\
\hline Luck & 176 & 11.76 & 13.48 & 27.89 & 0.85 & 1.00 \\
\hline Skill & 176 & 2.72 & 2.46 & 28.61 & 0.05 & 0.11 \\
\hline Bad luck & 176 & 0.24 & 0 & 0.43 & 0.94 & 0.94 \\
\hline Bad skill & 176 & 0.46 & 0 & 0.50 & 0.13 & 0.13 \\
\hline Compensation distance & 171 & -1786.18 & -135.54 & $6,529.21$ & 0.81 & 0.74 \\
\hline Low compensation indicator & 171 & 0.44 & 0 & 0.50 & 0.78 & 0.78 \\
\hline CDF compensation distance & 171 & 0.48 & 0.49 & 0.27 & 0.50 & 0.59 \\
\hline Market beta & 176 & 0.15 & 0.10 & 0.78 & 0.02 & 0.11 \\
\hline Return variance & 176 & 7.54 & 4.60 & 9.08 & 0.13 & 0.03 \\
\hline Idiosyncratic Variance & 176 & 1.82 & 1.63 & 0.88 & 0.71 & 0.31 \\
\hline Log revenue & 176 & 8.00 & 7.97 & 1.44 & 0.14 & 0.02 \\
\hline Book-to-Market & 176 & 0.55 & 0.41 & 0.53 & 0.26 & 0.84 \\
\hline Regulation & 176 & 0.03 & 0 & 0.17 & 0.52 & 0.51 \\
\hline Interlock & 176 & 0.06 & 0 & 0.23 & 0.24 & 0.25 \\
\hline Tenure & 176 & 7.73 & 7.66 & 0.73 & 0 & 0.16 \\
\hline Herfindahl & 176 & 0.04 & 0.03 & 0.03 & 0.93 & 0.06 \\
\hline Total compensation & 176 & $6,058.19$ & $4,362.86$ & $6,810.70$ & 0.15 & 0.16 \\
\hline Salary & 176 & 651.90 & 662.38 & 281.61 & 0.08 & 1.00 \\
\hline Bonus & 176 & 606.60 & 315.19 & 780.55 & 0.02 & 0.02 \\
\hline Other compensation & 176 & 323.64 & 103.90 & 690.18 & 0.49 & 0.69 \\
\hline Stock grants & 176 & $1,095.35$ & 0 & $1,786.55$ & 0.02 & 0.48 \\
\hline Option awards & 176 & $2,239.60$ & $1,140.67$ & $3,851.77$ & 0.01 & 1.00 \\
\hline
\end{tabular}

Panel E: Pre-spinoff correlation matrix

Firm stock return Peer return (industry-size)

Firm stock return

Peer return (industry-size)

$\begin{array}{lll}\text { Peer return (industry) } & 0.442 & 0.923\end{array}$

S\&P 500 return

0.366

0.517

0.432

Panel F: Post-spinoff correlation matrix

Firm stock return

Peer return (industry-size)

Peer return (industry)

S\&P 500 return

Firm stock return

Peer return (industry-size) $\quad 0.571$

Peer return (industry) $\quad 0.496$

S\&P 500 return

0.496
0.409

0.925

0.677

0.584

Panel G: Benchmark regressions

Pre-spinoff

Post-spinoff

\begin{tabular}{|c|c|c|c|c|}
\hline & Beta & Adjusted R-square & Beta & Adjusted R-square \\
\hline Peer return (industry-size) & 0.594 & 0.250 & 1.195 & 0.352 \\
\hline Peer return (industry) & 0.472 & 0.237 & 0.743 & 0.299 \\
\hline S\&P 500 return & 0.767 & 0.183 & 1.930 & 0.262 \\
\hline
\end{tabular}




\section{Table 3 - RPE pre- and post- spinoff parent firms}

This table tests RPE use for pre- and post-spinoff parent firms using Equation (1). Panel A uses $\log$ (total compensation) as the dependent variable and Panel B uses the change in log (total compensation) as the dependent variable. Variables are defined in Appendix A. All dollar values are in thousands (for compensation) or millions (for financial) of constant 1992 dollars. Hetereoskedasticity-consistent t-statistics clustered at the firm level are reported by each coefficient. *,**,*** denote significance at the $10 \%, 5 \%$, and $1 \%$ level respectively.

\begin{tabular}{|c|c|c|c|c|}
\hline \multirow{3}{*}{$\begin{array}{l}\text { Full sample regression } \\
\text { Independent variables }\end{array}$} & \multicolumn{2}{|l|}{ Panel A } & \multicolumn{2}{|l|}{ Panel B } \\
\hline & \multicolumn{2}{|c|}{ Log (compensation) } & \multicolumn{2}{|c|}{ Change in log (compensation) } \\
\hline & Coefficient & T-stat & Coefficient & T-stat \\
\hline Firm stock return $*$ pre-spinoff & -0.031 & -0.24 & -0.074 & -0.56 \\
\hline Peer return (industry-size) $*$ pre-spinoff & $0.503 * *$ & 2.27 & $0.455^{* *}$ & 2.44 \\
\hline Firm stock return $*$ post-spinoff & $0.172 * *$ & 2.03 & 0.173 & 1.33 \\
\hline Peer return (industry-size) * post-spinoff & -0.145 & -0.55 & -0.111 & -0.38 \\
\hline Log revenue & $0.412 * * *$ & 7.9 & 0.138 & 0.78 \\
\hline Book-to-Market & -0.072 & -0.49 & 0.094 & 1.01 \\
\hline Market beta & 0.051 & 0.73 & -0.020 & -0.55 \\
\hline Return variance & -0.007 & -1.37 & $-0.009 * *$ & -2.56 \\
\hline Regulation & $-0.936^{* * *}$ & -3.14 & -0.075 & -0.35 \\
\hline Interlock & $0.281^{*}$ & 1.78 & 0.030 & 0.3 \\
\hline Tenure & -0.03 & -0.57 & -0.020 & -0.54 \\
\hline Herfindahl & 0.968 & 0.24 & 2.945 & 0.97 \\
\hline Lag log (compensation) & & & $-0.212 * * *$ & -5.71 \\
\hline Year and industry fixed effects & Yes & & Yes & \\
\hline Adjusted R-square & 0.374 & & 0.119 & \\
\hline Number of observations & 729 & & 580 & \\
\hline Difference in Pre- and Post- coefficient & Difference & T-stat & Difference & T-stat \\
\hline Firm stock return & 0.203 & 1.6 & 0.247 & 1.58 \\
\hline Peer return (industry-size) & $-0.649 * *$ & -2.2 & $-0.566 *$ & -1.96 \\
\hline Pre-spinoff RPE test p-value & 0.041 & & 0.037 & \\
\hline Post-spinoff RPE test p-value & 0.912 & & 0.792 & \\
\hline
\end{tabular}


Table 4 - RPE pre- and post-spinoff using matched CEO sample

This table tests RPE use for pre- and post-spinoff firms using Equation (1). The sample includes pre- and post- spinoff firms where I was able to confirm the last CEO of the prespinoff firm stayed as CEO of the post-spinoff parent firm, so for this table, the CEO in the pre-spinoff firm sample is also in the post-spinoff parent firm sample. Panel A uses log (total compensation) as the dependent variable and Panel B uses the change in log (total compensation) as the dependent variable. Variables are defined in Appendix A. All dollar values are in thousands (for compensation) or millions (for financial) of constant 1992 dollars. Hetereoskedasticity-consistent t-statistics clustered at the firm level are reported by each coefficient. *, **, *** denote significance at the $10 \%, 5 \%$, and $1 \%$ level respectively.

\begin{tabular}{|c|c|c|c|c|}
\hline \multirow{3}{*}{$\begin{array}{l}\text { Matched CEOs regression } \\
\text { Independent variables }\end{array}$} & \multicolumn{2}{|l|}{ Panel A } & \multicolumn{2}{|l|}{ Panel B } \\
\hline & \multicolumn{2}{|c|}{ Log (compensation) } & \multicolumn{2}{|c|}{ Change in log (compensation) } \\
\hline & Coefficient & T-stat & Coefficient & T-stat \\
\hline Firm stock return $*$ pre-spinoff & -0.063 & -0.35 & -0.149 & -0.9 \\
\hline Peer return (industry-size) $*$ pre-spinoff & 0.256 & 0.89 & 0.181 & 0.86 \\
\hline Firm stock return $*$ post-spinoff & 0.057 & 0.28 & -0.072 & -0.3 \\
\hline Peer return (industry-size) * post-spinoff & 0.284 & 0.83 & 0.316 & 0.85 \\
\hline Log revenue & $0.384 * * *$ & 4.04 & 0.184 & 0.82 \\
\hline Book-to-Market & -0.277 & -1.09 & 0.090 & 0.6 \\
\hline Market beta & 0.08 & 0.83 & -0.037 & -0.85 \\
\hline Return variance & 0.002 & 0.19 & $-0.015 * *$ & -2.15 \\
\hline Regulation & -0.58 & -1.35 & -0.361 & -1.12 \\
\hline Interlock & 0.182 & 0.88 & 0.155 & 1.57 \\
\hline Tenure & -0.065 & -0.82 & -0.060 & -1.39 \\
\hline Herfindahl & 2.766 & 0.5 & -3.982 & -0.95 \\
\hline Lag log (compensation) & & & $-0.199 * * *$ & -3.92 \\
\hline Year and industry fixed effects & Yes & & Yes & \\
\hline Adjusted R-square & 0.357 & & 0.131 & \\
\hline Number of observations & 394 & & 330 & \\
\hline Difference in Pre- and Post- coefficient & Difference & T-stat & Difference & T-stat \\
\hline Firm stock return & 0.119 & 0.47 & 0.077 & 0.310 \\
\hline Peer return (industry-size) & 0.027 & 0.07 & 0.134 & 0.340 \\
\hline Pre-spinoff RPE test p-value & 0.494 & & 0.880 & \\
\hline Post-spinoff RPE test p-value & 0.202 & & 0.203 & \\
\hline
\end{tabular}




\section{Table 5 - Pay for skill/luck in pre- and post-spinoff parent firms}

This table tests pay for skill/luck in pre- and post-spinoff firms. Skill is defined as the alpha from equation 2 and luck is the average daily excess return over the fiscal year minus skill. Multiplying by 250 annualizes both skill and luck. Panel A uses log (total compensation) as the dependent variable and Panel B uses the change in log (total compensation) as the dependent variable. Variables are defined in Appendix A. All dollar values are in thousands (for compensation) or millions (for financial) of constant 1992 dollars. Hetereoskedasticity-consistent t-statistics clustered at the firm level are reported by each coefficient. *,**,*** denote significance at the $10 \%, 5 \%$, and $1 \%$ level respectively.

\begin{tabular}{|c|c|c|c|c|}
\hline \multirow{3}{*}{$\begin{array}{l}\text { Full sample regression } \\
\text { Independent variables }\end{array}$} & \multicolumn{2}{|l|}{ Panel A } & \multicolumn{2}{|l|}{ Panel B } \\
\hline & \multicolumn{2}{|c|}{ Log (compensation) } & \multicolumn{2}{|c|}{ Change in log (compensation) } \\
\hline & Coefficient & T-stat & Coefficient & T-stat \\
\hline Skill $*$ pre-spinoff & -0.001 & -0.62 & -0.001 & -0.77 \\
\hline Luck $*$ pre-spinoff & 0.003 & 0.94 & 0.002 & 1.29 \\
\hline Skill $*$ post-spinoff & $0.002 *$ & 1.77 & 0.001 & 1.23 \\
\hline Luck $*$ post-spinoff & 0.001 & 0.55 & $0.004 * *$ & 2.18 \\
\hline Log revenue & $0.415^{* * *}$ & 7.89 & 0.142 & 0.75 \\
\hline Book-to-Market & -0.067 & -0.46 & 0.102 & 1.79 \\
\hline Market beta & 0.055 & 0.79 & -0.015 & -0.57 \\
\hline Return variance & -0.006 & -1.24 & $-0.008 * *$ & -2.32 \\
\hline Regulation & $-0.903 * * *$ & -2.98 & -0.102 & -0.68 \\
\hline Interlock & $0.301 *$ & 1.88 & 0.028 & 0.26 \\
\hline Tenure & -0.032 & -0.61 & -0.011 & 0.15 \\
\hline Herfindahl & 1.363 & 0.33 & 2.021 & 0.47 \\
\hline Lag log (compensation) & & & $-0.203 * * *$ & -5.56 \\
\hline Year and industry fixed effects & Yes & & Yes & \\
\hline Adjusted R-square & 0.370 & & 0.113 & \\
\hline Number of observations & 729 & & 580 & \\
\hline Difference in Pre- and Post- coefficient & Difference & T-stat & Difference & T-stat \\
\hline Skill & 0.003 & 1.62 & 0.002 & 1.33 \\
\hline Luck & -0.002 & -0.53 & 0.001 & 0.73 \\
\hline
\end{tabular}




\section{Table 6 - Pay for skill/luck in pre- and post-spinoff firms using matched CEO sample}

This table tests pay for skill/luck in pre- and post-spinoff firms with matched CEOs. The sample includes pre- and post- spinoff firms where I was able to confirm the last CEO of the pre-spinoff firm stayed as CEO of the post-spinoff parent firm, so for this table, the CEO in the pre-spinoff firm sample is also in the post-spinoff parent firm sample. Skill is defined as the alpha from equation 2 and luck is the average daily excess return over the fiscal year minus skill. Multiplying by 250 annualizes both skill and luck. Panel A uses log (total compensation) as the dependent variable and Panel B uses the change in log (total compensation) as the dependent variable. Variables are defined in Appendix A. All dollar values are in thousands (for compensation) or millions (for financial) of constant 1992 dollars. Hetereoskedasticity-consistent t-statistics clustered at the firm level are reported by each coefficient. $*, * *, * * *$ denote significance at the $10 \%, 5 \%$, and $1 \%$ level respectively.

\begin{tabular}{|c|c|c|c|c|}
\hline \multirow{3}{*}{$\begin{array}{l}\text { Matched CEOs regression } \\
\text { Independent variables }\end{array}$} & \multicolumn{2}{|l|}{ Panel A } & \multicolumn{2}{|l|}{ Panel B } \\
\hline & \multicolumn{2}{|c|}{ Log (compensation) } & \multicolumn{2}{|c|}{ Change in log (compensation) } \\
\hline & Coefficient & T-stat & Coefficient & T-stat \\
\hline Skill $*$ pre-spinoff & 0.001 & 0.35 & -0.002 & -0.69 \\
\hline Luck $*$ pre-spinoff & 0.001 & 0.30 & 0.000 & 0.15 \\
\hline Skill * post-spinoff & 0.001 & 0.27 & -0.001 & -0.47 \\
\hline Luck $*$ post-spinoff & 0.003 & 1.04 & $0.005 * *$ & 2.05 \\
\hline Log revenue & $0.387 * * *$ & 4.06 & 0.164 & 0.70 \\
\hline Book-to-Market & -0.290 & -1.12 & 0.138 & 1.03 \\
\hline Market beta & 0.080 & 0.85 & -0.039 & -0.85 \\
\hline Return variance & 0.002 & 0.20 & $-0.016 * *$ & -2.51 \\
\hline Regulation & -0.619 & -1.44 & -0.441 & -1.39 \\
\hline Interlock & 0.173 & 0.82 & 0.141 & 1.37 \\
\hline Tenure & -0.066 & -0.82 & -0.052 & -1.19 \\
\hline Herfindahl & 2.427 & 0.43 & -5.343 & -1.26 \\
\hline Lag log (compensation) & & & $-0.190 * * *$ & -3.73 \\
\hline Year and industry fixed effects & Yes & & Yes & \\
\hline Adjusted R-square & 0.356 & & 0.144 & \\
\hline Number of observations & 394 & & 330 & \\
\hline Difference in Pre- and Post- coefficient & Difference & T-stat & Difference & T-stat \\
\hline Skill & 0.000 & -0.06 & 0.001 & 0.22 \\
\hline Luck & 0.002 & 0.73 & $0.004 *$ & 1.73 \\
\hline
\end{tabular}




\section{Table 7 - Asymmetry in pay for skill/luck for pre- and post-spinoff parent firms}

This table tests for asymmetry in pay for skill/luck in pre- and post-spinoff firms. Skill is defined as the alpha from equation 2 and luck is the average daily excess return over the fiscal year minus skill. Multiplying by 250 annualizes both skill and luck. Panel A uses log (total compensation) as the dependent variable and Panel B uses the change in log (total compensation) as the dependent variable. Variables are defined in Appendix A. All dollar values are in thousands (for compensation) or millions (for financial) of constant 1992 dollars. Hetereoskedasticity-consistent $\mathrm{t}$-statistics clustered at the firm level are reported by each coefficient. $*, * *, * * *$ denote significance at the $10 \%, 5 \%$, and $1 \%$ level respectively.

\begin{tabular}{|c|c|c|c|c|}
\hline \multirow{3}{*}{$\begin{array}{l}\text { Full sample regression } \\
\text { Independent variables }\end{array}$} & \multicolumn{2}{|l|}{ Panel A } & \multicolumn{2}{|l|}{ Panel B } \\
\hline & \multicolumn{2}{|c|}{ Log (compensation) } & \multicolumn{2}{|c|}{ Change in log (compensation) } \\
\hline & Coefficient & T-stat & Coefficient & T-stat \\
\hline Skill $*$ pre-spinoff & 0.003 & 0.94 & -0.001 & -0.19 \\
\hline Luck $*$ pre-spinoff & $0.006^{*}$ & 1.67 & 0.003 & 1.15 \\
\hline Skill $*$ bad skill $*$ pre-spinoff & -0.007 & -1.39 & -0.001 & -0.16 \\
\hline Luck $*$ bad luck $*$ pre-spinoff & -0.011 & -1.62 & -0.002 & -0.32 \\
\hline Skill $*$ post-spinoff & 0.003 & 1.14 & 0.001 & 0.26 \\
\hline Luck $*$ post-spinoff & $0.007 * *$ & 2.33 & $0.004 *$ & 1.76 \\
\hline Skill $*$ bad skill $*$ post-spinoff & -0.002 & -0.55 & 0.001 & 0.14 \\
\hline Luck $*$ bad luck $*$ post-spinoff & $-0.020 * * *$ & -3.53 & -0.002 & -0.39 \\
\hline Other control variables & Yes & & Yes & \\
\hline Year and industry fixed effects & Yes & & Yes & \\
\hline Adjusted R-square & 0.379 & & 0.107 & \\
\hline Number of observations & 729 & & 580 & \\
\hline Difference in Pre- and Post- coefficient & Difference & T-stat & Difference & T-stat \\
\hline Skill & 0.000 & 0.08 & 0.001 & 0.440 \\
\hline Luck & 0.001 & 0.27 & 0.002 & 0.550 \\
\hline Skill * bad skill & 0.005 & 0.83 & 0.002 & 0.3 \\
\hline Luck * bad luck & -0.009 & -1.06 & 0.000 & -0.04 \\
\hline
\end{tabular}


Table 8 - Asymmetry in pay for skill/luck using the matched CEO sample

This table tests pay for asymmetry in pay for skill/luck in pre- and post-spinoff firms with matched CEOs. The sample includes pre- and post- spinoff firms where I was able to confirm the last CEO of the pre-spinoff firm stayed as CEO of the post-spinoff parent firm, so for this table, the CEO in the pre-spinoff firm sample is also in the post-spinoff parent firm sample. Skill is defined as the alpha from equation 2 and luck is the average daily excess return over the fiscal year minus skill. Multiplying by 250 annualizes both skill and luck. Panel A uses log (total compensation) as the dependent variable and Panel B uses the change in $\log$ (total compensation) as the dependent variable. Variables are defined in Appendix A. All dollar values are in thousands (for compensation) or millions (for financial) of constant 1992 dollars. Hetereoskedasticity-consistent t-statistics clustered at the firm level are reported by each coefficient. *,**, *** denote significance at the $10 \%$, $5 \%$, and $1 \%$ level respectively.

\begin{tabular}{|c|c|c|c|c|}
\hline \multirow{3}{*}{$\begin{array}{l}\text { Matched CEOs regression } \\
\text { Independent variables }\end{array}$} & \multicolumn{2}{|c|}{ Panel A } & \multicolumn{2}{|l|}{ Panel B } \\
\hline & \multicolumn{2}{|c|}{ Log (compensation) } & \multicolumn{2}{|c|}{ Change in log (compensation) } \\
\hline & Coefficient & T-stat & Coefficient & T-stat \\
\hline Skill $*$ pre-spinoff & 0.007 & 1.40 & 0.002 & 0.45 \\
\hline Luck * pre-spinoff & 0.004 & 0.82 & 0.000 & 0.05 \\
\hline Skill $*$ bad skill $*$ pre-spinoff & -0.010 & -1.30 & -0.006 & -0.92 \\
\hline Luck $*$ bad luck $*$ pre-spinoff & -0.009 & -1.03 & -0.001 & -0.13 \\
\hline Skill $*$ post-spinoff & -0.003 & -0.58 & -0.005 & -1.09 \\
\hline Luck * post-spinoff & $0.011 * *$ & 2.41 & $0.010 * * *$ & 3.00 \\
\hline Skill $*$ bad skill $*$ post-spinoff & 0.007 & 1.00 & 0.008 & 1.12 \\
\hline Luck $*$ bad luck $*$ post-spinoff & $-0.020 * *$ & -2.15 & $-0.013 * *$ & -2.09 \\
\hline Other control variables & Yes & & Yes & \\
\hline Year and industry fixed effects & Yes & & Yes & \\
\hline Adjusted R-square & 0.361 & & 0.152 & \\
\hline Number of observations & 394 & & 330 & \\
\hline Difference in Pre- and Post- coefficient & Difference & T-stat & Difference & T-stat \\
\hline Skill & $-0.009 *$ & -1.73 & -0.007 & -1.5 \\
\hline Luck & 0.007 & 1.3 & $0.010 * * *$ & 2.7 \\
\hline Skill * bad skill & $0.016 * *$ & 2.05 & $0.014 *$ & 1.92 \\
\hline Luck * bad luck & -0.011 & -1.01 & $-0.012 * *$ & -2.11 \\
\hline
\end{tabular}




\section{Table 9 - Benchmarking CEO compensation with low compensation indicator}

This table tests compensation benchmarking in pre- and post-spinoff parent firms. Low comp ind is an indicator variable equal to one if the firm's prior year compensation was below the median compensation of its industry-size benchmark, and zero otherwise. Panel $\mathrm{A}$ is the full sample, and Panel B is the matched CEO sample where the CEO in the prespinoff firm sample is also the CEO for the post-spinoff parent firm. Variables are defined in Appendix A. All dollar values are in thousands (for compensation) or millions (for financial) of constant 1992 dollars. Hetereoskedasticity-consistent t-statistics clustered at the firm level are reported by each coefficient. *, **, *** denote significance at the $10 \%$, $5 \%$, and $1 \%$ level respectively.

\section{Panel A - Full sample regression}

\begin{tabular}{lll} 
& \multicolumn{2}{l}{ Change in log (compensation) } \\
\cline { 2 - 3 } Independent variables & Coefficient & T-stat \\
\hline Low comp ind * pre-spinoff & $0.147^{*}$ & 1.810 \\
Low comp ind * post-spinoff & $0.211^{* *}$ & 2.620 \\
Log revenue & 0.162 & 0.880 \\
Book-to-Market & 0.002 & 0.030 \\
Market beta & -0.022 & -0.570 \\
Return variance & $-0.006^{*}$ & -1.700 \\
Regulation & 0.077 & 0.340 \\
Interlock & 0.033 & 0.340 \\
Tenure & -0.009 & -0.240 \\
Herfindahl & 4.728 & 1.400 \\
Lag log (compensation) & $-0.156^{* * *}$ & -3.9 \\
\hline & & \\
Year and industry fixed effects & Yes & \\
Adjusted R-square & 0.116 & \\
Number of observations & 580 & T-stat \\
\hline
\end{tabular}

Panel B - Matched CEOs regression

\begin{tabular}{lll} 
& \multicolumn{2}{l}{ Change in log (compensation) } \\
\cline { 2 - 3 } Independent variables & Coefficient & T-stat \\
\hline Low comp ind * pre-spinoff & $0.177^{*} *$ & 2.200 \\
Low comp ind * post-spinoff & 0.124 & 1.200 \\
Log revenue & 0.184 & 0.770 \\
Book-to-Market & 0.158 & 1.390 \\
Market beta & -0.043 & -0.980 \\
Return variance & $-0.016^{* * *}$ & -2.300 \\
Regulation & -0.288 & -0.850 \\
Interlock & 0.160 & 1.610 \\
Tenure & -0.051 & -1.240 \\
Herfindahl & -2.150 & -0.490 \\
Lag log (compensation) & $-0.157 * * *$ & -2.78 \\
\hline & & \\
Year and industry fixed effects & Yes & \\
Adjusted R-square & 0.138 & \\
Number of observations & 330 & T-stat \\
\hline & & -0.53 \\
Difference in Pre- and Post- coefficient & & \\
\hline Low comp ind & Difference & -0.054 \\
\hline
\end{tabular}




\section{Table 10 - Benchmarking CEO compensation with CDF measure}

This table tests compensation benchmarking in pre- and post-spinoff parent firms. CDF comp distance is the cumulative distribution function of the prior year median total compensation from the industry-size group minus the prior year total compensation of the firm in the same industry-size group. CDF comp distance is low if the prior year compensation was low relative to the median industry-size compensation. Panel A is the full sample, and Panel B is the matched CEO sample where the CEO in the pre-spinoff firm sample is also the CEO for the post-spinoff parent firm. Variables are defined in Appendix A. All dollar values are in thousands (for compensation) or millions (for financial) of constant 1992 dollars. Hetereoskedasticity-consistent t-statistics clustered at the firm level are reported by each coefficient. *, **, *** denote significance at the $10 \%$, $5 \%$, and $1 \%$ level respectively.

\begin{tabular}{|c|c|c|}
\hline \multicolumn{3}{|l|}{ Panel A - Full sample regression } \\
\hline Independent variables & Coefficient & T-stat \\
\hline CDF comp distance $*$ pre-spinoff & $0.723 * * *$ & 4.250 \\
\hline CDF comp distance $*$ post-spinoff & $0.759 * * *$ & 4.370 \\
\hline Log revenue & 0.156 & 0.850 \\
\hline Book-to-Market & -0.032 & -0.480 \\
\hline Market beta & -0.017 & -0.430 \\
\hline Return variance & -0.004 & -1.260 \\
\hline Regulation & 0.205 & 0.920 \\
\hline Interlock & 0.015 & 0.140 \\
\hline Tenure & -0.005 & -0.140 \\
\hline Herfindahl & 4.909 & 1.510 \\
\hline Lag log (compensation) & -0.06 & -1.27 \\
\hline Year and industry fixed effects & Yes & \\
\hline Adjusted R-square & 0.146 & \\
\hline Number of observations & 580 & \\
\hline Difference in Pre- and Post- coefficient & Difference & T-stat \\
\hline CDF comp distance & 0.036 & 0.34 \\
\hline \multicolumn{3}{|l|}{ Panel B - Matched CEOs regression } \\
\hline & \multicolumn{2}{|c|}{ Change in log (compensation) } \\
\hline Independent variables & Coefficient & T-stat \\
\hline CDF comp distance $*$ pre-spinoff & $0.538 * * *$ & 3.150 \\
\hline CDF comp distance $*$ post-spinoff & $0.518 * * *$ & 2.780 \\
\hline Log revenue & 0.213 & 0.910 \\
\hline Book-to-Market & 0.147 & 1.320 \\
\hline Market beta & -0.039 & -0.890 \\
\hline Return variance & $-0.015^{* *}$ & -2.000 \\
\hline Regulation & -0.173 & -0.540 \\
\hline Interlock & 0.128 & 1.210 \\
\hline Tenure & -0.042 & -1.020 \\
\hline Herfindahl & -1.732 & -0.410 \\
\hline Lag log (compensation) & -0.089 & -1.51 \\
\hline Year and industry fixed effects & Yes & \\
\hline Adjusted R-square & 0.155 & \\
\hline Number of observations & 330 & \\
\hline Difference in Pre- and Post- coefficient & Difference & T-stat \\
\hline CDF comp distance & -0.02 & -0.16 \\
\hline
\end{tabular}




\section{Table 11 - Matched sample descriptive statistics}

Panel A provides summary statistics on the pre-spinoff matched sample. Panel B details post-spinoff matched firms. Compensation data are denominated in thousands of constant 1992 dollars. Financial data are denominated in millions of constant 1992 dollars. Variable definitions are in Appendix A.

\begin{tabular}{|c|c|c|c|c|c|c|}
\hline \multirow[b]{2}{*}{ Variable } & \multirow[b]{2}{*}{$\mathrm{N}$} & \multirow[b]{2}{*}{ Mean } & \multirow[b]{2}{*}{ Median } & \multirow[b]{2}{*}{ Std dev } & \multicolumn{2}{|c|}{$\begin{array}{l}\text { Test statistic for pre- versus post- } \\
\text { spinoff differences in the }\end{array}$} \\
\hline & & & & & Mean (p-value) & Median (p-value) \\
\hline Log total compensation & 334 & 8.10 & 8.10 & 1.03 & 0.12 & 0.166 \\
\hline Firm stock return & 334 & 0.18 & 0.12 & 0.43 & 0.23 & 0.204 \\
\hline Peer return (industry-size) & 334 & 0.13 & 0.12 & 0.26 & 0.33 & 0.513 \\
\hline Peer return (industry) & 334 & 0.16 & 0.14 & 0.32 & 0.81 & 0.265 \\
\hline Luck & 334 & 13.99 & 13.19 & 25.55 & 0.59 & 0.908 \\
\hline Skill & 334 & 0.79 & 0.52 & 31.62 & 0.64 & 0.419 \\
\hline Bad luck & 334 & 0.22 & 0 & 0.41 & 0.03 & 0.026 \\
\hline Bad skill & 334 & 0.49 & 0 & 0.50 & 0.42 & 0.419 \\
\hline Compensation distance & 270 & $(1,768.23)$ & $(330.53)$ & $5,278.03$ & 0.77 & 0.866 \\
\hline Low compensation indicator & 270 & 0.39 & 0 & 0.49 & 0.59 & 0.589 \\
\hline CDF compensation distance & 270 & 0.48 & 0.43 & 0.28 & 0.82 & 0.498 \\
\hline Market beta & 334 & 1.02 & 0.98 & 0.57 & 0.40 & 0.672 \\
\hline Return variance & 334 & 6.94 & 4.09 & 8.46 & 0.06 & 0.098 \\
\hline Idiosyncratic Variance & 334 & 1.91 & 1.64 & 1 & 0.77 & 0.97 \\
\hline Log revenue & 334 & 7.98 & 8.09 & 1.37 & 0.08 & 0.564 \\
\hline Book-to-Market & 334 & 0.60 & 0.47 & 0.57 & 0.32 & 0.672 \\
\hline Regulation & 334 & 0.04 & 0 & 0.19 & 0.89 & 0.888 \\
\hline Interlock & 334 & 0.06 & 0 & 0.24 & 0.02 & 0.018 \\
\hline Tenure & 313 & 7.59 & 7.69 & 0.97 & 0.01 & 0.015 \\
\hline Herfindahl & 334 & 0.04 & 0.03 & 0.04 & 0.70 & 0.024 \\
\hline
\end{tabular}


Panel B: Post-spinoff matched firms

\begin{tabular}{|c|c|c|c|c|c|c|}
\hline \multirow[b]{2}{*}{ Variable } & \multirow[b]{2}{*}{$\mathrm{N}$} & \multirow[b]{2}{*}{ Mean } & \multirow[b]{2}{*}{ Median } & \multirow[b]{2}{*}{ Std dev } & \multicolumn{2}{|c|}{$\begin{array}{l}\text { Test statistic for pre- versus post- } \\
\text { spinoff differences in the }\end{array}$} \\
\hline & & & & & Mean (p-value) & Median (p-value) \\
\hline Log total compensation & 340 & 8.22 & 8.26 & 0.93 & 0.12 & 0.17 \\
\hline Firm stock return & 341 & 0.14 & 0.08 & 0.46 & 0.23 & 0.20 \\
\hline Peer return (industry-size) & 341 & 0.11 & 0.11 & 0.29 & 0.33 & 0.51 \\
\hline Peer return (industry) & 341 & 0.17 & 0.13 & 0.39 & 0.81 & 0.27 \\
\hline Luck & 341 & 12.85 & 13.85 & 28.57 & 0.59 & 0.91 \\
\hline Skill & 341 & $(0.32)$ & $(0.98)$ & 28.95 & 0.64 & 0.42 \\
\hline Bad luck & 341 & 0.29 & 0 & 0.46 & 0.03 & 0.03 \\
\hline Bad skill & 341 & 0.52 & 1.00 & 0.50 & 0.42 & 0.42 \\
\hline Compensation distance & 292 & $(1,908.07)$ & $(385.42)$ & $5,868.33$ & 0.77 & 0.87 \\
\hline Low compensation indicator & 292 & 0.41 & 0.00 & 0.49 & 0.59 & 0.59 \\
\hline CDF compensation distance & 292 & 0.48 & 0.45 & 0.28 & 0.82 & 0.50 \\
\hline Market beta & 341 & 1.06 & 1.00 & 0.57 & 0.40 & 0.67 \\
\hline Return variance & 341 & 8.25 & 4.71 & 9.64 & 0.06 & 0.10 \\
\hline Idiosyncratic Variance & 341 & 1.88 & 1.64 & 1.03 & 0.77 & 0.97 \\
\hline Log revenue & 341 & 8.17 & 8.23 & 1.36 & 0.08 & 0.56 \\
\hline Book-to-Market & 341 & 0.64 & 0.48 & 0.60 & 0.32 & 0.67 \\
\hline Regulation & 341 & 0.04 & 0 & 0.20 & 0.89 & 0.89 \\
\hline Interlock & 341 & 0.02 & 0 & 0.15 & 0.02 & 0.02 \\
\hline Tenure & 333 & 7.39 & 7.46 & 0.93 & 0.01 & 0.02 \\
\hline Herfindahl & 341 & 0.04 & 0.03 & 0.04 & 0.70 & 0.02 \\
\hline
\end{tabular}




\section{Table 12 - Matched sample RPE tests}

This table tests RPE use for pre- and post-spinoff matched firms using Equation (1). Panel A uses log (total compensation) as the dependent variable and Panel B uses the change in $\log$ (total compensation) as the dependent variable. Variables are defined in Appendix A. All dollar values are in thousands (for compensation) or millions (for financial) of constant 1992 dollars. Hetereoskedasticity-consistent t-statistics clustered at the firm level are reported by each coefficient. *,**,*** denote significance at the $10 \%, 5 \%$, and $1 \%$ level respectively.

\begin{tabular}{|c|c|c|c|c|}
\hline \multirow{3}{*}{$\begin{array}{l}\text { Matched sample regression } \\
\text { Independent variables }\end{array}$} & \multicolumn{2}{|l|}{ Panel A } & \multicolumn{2}{|l|}{ Panel B } \\
\hline & \multicolumn{2}{|c|}{ Log (compensation) } & \multicolumn{2}{|c|}{ Change in log (compensation) } \\
\hline & Coefficient & T-stat & Coefficient & T-stat \\
\hline Firm stock return $*$ pre-spinoff & $0.446 * * *$ & 3.31 & $0.357 * * *$ & 2.71 \\
\hline Peer return (industry-size) $*$ pre-spinoff & -0.176 & -0.88 & -0.014 & -0.07 \\
\hline Firm stock return $*$ post-spinoff & 0.036 & 0.39 & 0.088 & 0.72 \\
\hline Peer return (industry-size) $*$ post-spinoff & -0.3 & -1.64 & -0.272 & -1.31 \\
\hline Log revenue & $0.462 * * *$ & 12.83 & $0.000 * *$ & 2.26 \\
\hline Book-to-Market & $-0.295 * * *$ & -3.03 & $0.086^{*}$ & 1.86 \\
\hline Market beta & $0.558 * * *$ & 5.98 & 0.127 & 1.48 \\
\hline Return variance & -0.01 & -1.44 & $-0.012 * * *$ & -2.8 \\
\hline Regulation & -0.044 & -0.13 & 0.059 & 0.25 \\
\hline Interlock & -0.035 & -0.16 & 0.024 & 0.18 \\
\hline Tenure & $0.061 *$ & 1.85 & 0.035 & 0.77 \\
\hline Herfindahl & $8.997 * *$ & 2.45 & -0.256 & -0.08 \\
\hline Lag log (compensation) & & & $-0.274 * * *$ & -6.49 \\
\hline Year and industry fixed effects & Yes & & Yes & \\
\hline Adjusted R-square & 0.528 & & 0.208 & \\
\hline Number of observations & 646 & & 535 & \\
\hline Difference in Pre- and Post- coefficient & Difference & T-stat & Difference & T-stat \\
\hline Firm stock return & -0.176 & -0.88 & -0.014 & -0.07 \\
\hline Peer return (industry-size) & -0.124 & -0.58 & -0.272 & -1.31 \\
\hline Pre-spinoff RPE test p-value & 0.108 & & 0.031 & \\
\hline Post-spinoff RPE test p-value & 0.131 & & 0.335 & \\
\hline
\end{tabular}




\section{CHAPTER 2: REFERENCE POINTS IN CEO COMPENSATION}

\section{Introduction}

I examine the use of reference points in setting CEO compensation and discuss how reference points are related to two psychological phenomena: prospect theory and anchoring-and-adjusting. These behavioral phenomena have been used to help explain a number of aspects of decision making. For example, prospect theory has been linked to investors selling shares of stock that increase in value, while holding shares of stock that decrease in value. This phenomenon is known as the disposition effect (Shefrin and Statman, 1985; Barberis and Xiong, 2009). Anchoring-and-adjusting has been shown to influence analysts' forecasts (Campbell and Sharpe, 2009; Amir and Ganzach, 1998). The research question I address is: Is there evidence that these behavioral phenomena affect CEO compensation?

\section{Prospect Theory}

Prospect theory was developed by Kahneman and Tversky (1979). The theory stipulates that decisions involving risk exhibit three characteristics: (i) utility is driven by changes in status relative to a reference point; (ii) losses are disliked more than equalsized gains are liked (loss-aversion); and (iii) utility is less sensitive to marginal gains/losses as you move further away from the reference point. As shown in Figure 1, the corresponding value function has a kink at the reference point (origin), where the value function is concave over gains and convex over losses relative to the reference point. A large body of experimental evidence supports the Kahneman and Tversky 
model. Loss aversion, in particular, is widely supported across multiple research disciplines (Kahneman and Tversky, 2000; Post et al., 2008; Camerer et al., 2011; Chen et al., 2006; among others).

I examine whether the use of prospect-theory preferences influences CEO compensation in two settings. First, I use a sample of CEOs who move from one company to another to determine if the incoming CEOs display prospect theory preferences. I use the incoming CEO's prior compensation level as the reference point in this test. Because prospect theory incorporates loss aversion, it makes sense to use a compensation level associated with the incoming CEO, who is likely to be loss averse to lower compensation levels (relative to her reference point-her prior compensation).

The compensation of the incoming CEO's predecessor can also be viewed as a reference point from the perspective of the board. However, because the board is not likely to be loss averse when setting the compensation of the incoming CEO, I do not use the compensation of the incoming CEO's predecessor as a reference point when testing prospect theory.

If the incoming CEOs have prospect theory preferences, they will be more upset over pay cuts than they will be happy about pay increases of the same magnitude (cuts and increases relative to their compensation at the previous company). Because of the different perceptions of losses vs. gains, the CEOs who expect to receive a pay cut will negotiate more ardently than the CEOs that expect to receive a pay increase. This reasoning leads to my first hypothesis:

Hypothesis 1: For predicted pay cuts and increases of the same magnitude, the decrease in compensation for incoming CEOs who are predicted to 
take a pay cut relative to their compensation at their previous company will be less than the increase in compensation for incoming CEOs who are predicted to receive a pay increase.

Recent studies on CEO compensation have employed Kahneman and Tversky's prospect theory model. Dittmann, Maug, and Spalt (2010) calibrate a principal-agent model with loss-averse agents (CEOs). When they set the reference point close to the fixed portion of compensation (bonus plus salary), the loss-averse model generates convex compensation contracts that closely approximate observed contracts. When they use the standard constant relative risk aversion (CRRA) model, the contracts generated by the model are concave and do not approximate observed contracts well. My study provides additional evidence on prospect theory preferences used in CEO compensation; however, I use an empirical approach, not simulations.

The second setting I use to examine prospect theory is recent highs and lows in stock price, and I determine if the high/low prices act as reference points when setting CEO compensation. Recent high/low prices, such as the 52-week high/low price, are commonly reported and discussed in the financial press. The high/low prices could act as reference points to investors and, more important, members of the compensation committee. Kahneman (1992) states that it is possible to have multiple reference points that can be formed by normatively irrelevant references or by aspirational levels or expectations. Unlike individual purchase price reference points that have been used by previous studies, high/low prices are common to all market participants.

When the fiscal year end price is at or near a recent high price, loss-averse investors will be the most satisfied with management, and the board will feel justified 
(and have a lower threat of investor backlash) in granting higher compensation to the CEO than would be expected based on firm, managerial, and performance characteristics. Conversely, when the fiscal year end price is at or near a recent low price, loss-averse investors will be the most dissatisfied with management, and the board may face pressure to cut or limit CEO compensation.

Recent high/low prices have been shown to be relevant to both shareholders and managers. Baker, Pan, and Wurgler (2012) find that recent stock price peaks act as a reference point for offer prices, and an offer's probability of acceptance jumps discontinuously when it exceeds a peak price. Huddart, Lang, and Yetman (2009) find abnormally high trading activity when a stock price crosses a previous 52-week high or low price. Additionally, advisory firms such as Institutional Shareholder Services Inc. (ISS) use the 52-week high price when advising on stock option repricing.

If recent high/low stock prices act as reference points, I expect the percent change from the recent high/low price to the fiscal year end price to influence CEO compensation. Larger percent declines (increases) from the recent high (low) price to the fiscal year end price should result in larger decreases (increases) in compensation, holding all else constant. Additionally, because of the loss-aversion property, declines from the recent high price will be penalized more than equal-sized increases from the recent low price will be rewarded. This reasoning leads to my second hypothesis:

Hypothesis 2: Declines from the recent high price to the fiscal year end price will decrease CEO compensation to a greater degree than increases from the recent low price to the fiscal year end price will increase compensation. 


\section{Anchoring-and-adjusting}

The second behavioral phenomenon I examine in this paper is anchoring-andadjusting. Anchoring refers to a decision maker being influenced by an initial value for an unknown quantity before estimating that quantity. Even though the initial value may be irrelevant to the decision at hand, it acts as a reference point that is used to help estimate an unknown quantity. Subsequent estimations of the unknown quantity are then made by gradually adjusting away from the initial value.

For example, when negotiating a selling price for a car, a seller can initially offer to sell the car for $\$ 20,000$. The $\$ 20,000$ is the initial value that acts as a reference point. If the seller then cuts the price to $\$ 17,000$, the buyer will think he is getting a better deal than if the seller originally offered the car for $\$ 17,000$. The buyer is using the reference point of $\$ 20,000$ and comparing the subsequent offer of $\$ 17,000$ to the $\$ 20,000$ reference point.

Like prospect theory, anchoring has also received support from multiple research disciplines (Tversky and Kahneman, 1974; Northcraft and Neale, 1987; Bergman et al., 2010; among others). Anchoring-and-adjusting is a similar phenomenon to prospect theory, but anchoring deals with the formation of beliefs, whereas prospect theory outlines how people perceive utility.

To test for the use of anchoring-and-adjusting in setting CEO compensation, I again use the sample of CEOs that move from one company to another. The compensation for the incoming CEO's predecessor acts as the reference point that the board uses as an anchor when setting the incoming CEO's compensation. If the incoming 
CEO's predecessor was paid more than a comparable CEO, anchoring by the board would suggest that the incoming CEO will see higher increases in compensation from her prior company to her new company. This reasoning leads to my third hypothesis.

Hypothesis 3: If the incoming CEO's predecessor was paid a premium relative to comparable CEOs, the incoming CEO will receive a higher increase in compensation from her prior company to her new company.

This study provides evidence on how well documented behavioral phenomena affect CEO compensation. The CEO mover sample examines how compensation is set in the initial years that a CEO is with a company. Because CEO compensation levels are positively auto-correlated across time, it is important to understand how these initial contracts are set when a CEO arrives at a firm. Also, re-contracting costs may prevent alterations in contracts for CEOs who have been in the same position for an extended period.

\section{Testing Loss Aversion and Anchoring-and-Adjusting}

CEO mover sample - loss aversion

I follow an empirical model similar to Bokhari and Geltner (2011) to test for loss aversion and anchoring-and-adjusting. I use the following equation:

Change in CEOPay ${ }_{i t}=\mathrm{a}_{0}+\mathrm{a}_{1}$ Gain $_{\mathrm{it}}+\mathrm{a}_{2}$ Loss $_{\mathrm{it}}+\mathrm{a}_{3}$ Anchor $_{\mathrm{it}}+\mathrm{a}_{4}$ ControlVariables $_{\mathrm{it}}+\mathrm{e}_{\mathrm{it}}(1)$

Subscript $t$ indicates the year and subscript $\mathrm{i}$ is a firm identifier. The main independent variable of interest for the loss aversion test is the proxy for the incoming CEO's predicted gain/loss relative to the CEO's prior compensation (i.e., the reference point). To construct this proxy, I define the Gain and Loss variables as follows: 
Gain $=$ natural log of the average comparable $\mathrm{CEO}$ compensation minus the natural log of the incoming CEO's prior compensation, defined where the incoming CEO's prior compensation is less than the average comparable CEO compensation, and zero otherwise.

Loss $=$ natural log of the incoming CEO's prior compensation minus the average comparable CEO compensation, defined where the incoming CEOs prior compensation is more than the average comparable CEO compensation, and zero otherwise.

Hypothesis 1 predicts that a will be positive, a will be negative, and $a_{2}$ will be significantly less than $a_{1}$ in magnitude.

The average comparable CEO compensation for these variables is my proxy for what the incoming CEO expects to receive for compensation at the new job based on firm and personal characteristics. I construct the average comparable compensation proxy in two ways: (i) using the median compensation from a group of peer firms in the same industry and with a similar market capitalization and (ii) through a hedonic regression.

The hedonic regression is used to identify the magnitude of the determinants of compensation in order to approximate compensation that the mover CEOs can expect to receive at the new firms they go to. To run the hedonic regressions, I use a rolling windows approach to estimate the compensation determinant coefficients. Each year, I estimate the following equation using the past three years of data on all possible firms in Execucomp.

$$
\begin{aligned}
& \mathrm{CEOPay}_{\mathrm{it}}=\mathrm{a}_{1} \log (\text { total assets })_{\mathrm{it}-1}+\mathrm{a}_{2} \text { Market-to-book } \mathrm{it}_{-1}+\mathrm{a}_{3} \text { Stock return }_{\mathrm{it}}+ \\
& \mathrm{a}_{4} \mathrm{ROA}_{i t}+\mathrm{a}_{5} \mathrm{CEO} \text {-chair-indicator }{ }_{i t}+\mathrm{a}_{6} \text { Industry fixed effects } i t+\mathrm{e}_{\mathrm{it}}
\end{aligned}
$$


The dependent variable is either the log of total compensation or salary plus bonus. The independent variables are other determinants of compensation. After I estimate the coefficients $\mathrm{a}_{1}$ through $\mathrm{a}_{6}$, I use the coefficients to predict the compensation (both total compensation and salary plus bonus) for the CEOs in my mover sample at their new firm.

\section{CEO mover sample - anchoring}

The main independent variable of interest for the anchoring test is:

Anchor $=$ the average comparable CEO compensation for the incoming CEO's predecessor minus the compensation for the incoming CEO's predecessor in the year prior to the incoming CEO's first observation at the new firm in Execucomp.

The average comparable CEO compensation for the Anchor variable is what the incoming CEO's predecessor should have expected her compensation to be based on firm and personal characteristics. Consistent with the compensation benchmarking literature, I use the median compensation from a peer group to approximate the average compensation variable. Hypothesis 3 predicts that the coefficient a from Equation (1) will be negative and significantly different from zero.

The anchor variable I use is similar to compensation distance measures that are used in compensation benchmarking studies (Bizjak, Lemmon, and Naveen, 2008; Faulkender and Yang, 2010; among others). A robust finding in benchmarking studies is that the compensation distance measure is positively related to changes in CEO compensation (i.e., CEOs who receive lower compensation than the median compensation of their peer group in the prior year receive higher increases in compensation in the following year). The main difference between my study and prior 
benchmarking studies is that I use a sample where the prior year's CEO is different than the current CEO. As a result, my dependent variable uses compensation from the CEO's prior firm and the new firm to which the CEO moves. Most benchmarking studies only include observations where the current $\mathrm{CEO}$ is also the prior year's $\mathrm{CEO}$, and the dependent variable measures year-over-year changes in compensation. Because of these different approaches, results consistent with Hypothesis 3 will not be replicating CEO compensation benchmarking findings.

There is little theory to motivate what the appropriate compensation measure should be, so I use a number of specifications for the dependent variable, CEOPayit, similar to Dittmann, Maug, and Spalt (2010) where the compensation measure ranges from the CEO's base salary and bonus (fixed part of compensation) to total compensation (fixed plus variable compensation).

I use additional control variables to account for factors other than the reference points that influence compensation. These controls include firm size, market to book, firm performance, stock return volatility, CEO chair indicator, hire from the same industry, and year fixed effects.

\section{Recent high/low prices as reference points}

When testing if recent high/low prices act as reference points in setting CEO compensation, I use the following equation:

CEOPay ${ }_{i t}=\mathrm{a}_{0}+\mathrm{a}_{1}$ High_Change $\mathrm{it}_{\mathrm{it}}+\mathrm{a}_{2}$ Low_Change $_{\mathrm{it}}+\mathrm{a}_{3}$ ControlVariablesit $+\mathrm{e}_{\mathrm{it}}(3)$

Subscript $t$ indicates the year and subscript $\mathrm{i}$ is a firm identifier. The main independent variables of interest are the High_Change and Low_Change variables. High_Change is defined as the percent change from the fiscal year high price (most 
recent 13-, 26-, and 52-week high price) to the fiscal year end price (this variable has a range from negative one to zero). Low_Change is the percent change from the fiscal year low price (again using 13-, 26-, and 52-week low prices) to the fiscal year end price (this variable has a range from zero to infinity).

Hypothesis 2 predicts that $\mathrm{a}_{1}$ from Equation (3) will be positive and significantly different from zero, $a_{2}$ will be positive and significantly different from zero, and $a_{1}$ will be significantly greater than $a_{2}$. Because I use the full Execucomp dataset on this section, I include CEO fixed effects in addition to the control variables defined for Equation (1) as recommended by Graham, Li, and Qiu (2012).

\section{Data and Sample Selection}

CEO mover sample

I first identify CEOs in Execucomp using the CEOANN variable. Next I sort by EXECID (executive identifier) and YEAR and keep only observations where the EXECID is the same as the lag EXECID and the GVKEY (firm identifier) is not the same as the lag GVKEY. This approach yields 459 observations from 1992 - 2013. After excluding observations where the CEO does not actually move from one firm to another even though the firm identifier changes from the previous year (most common for companies that had a change in name because of an acquisition or spinoff), I am left with 283 observations. My final sample after merging with CRSP and Compustat is 159 CEOs who left one company and moved to another.

For incoming CEOs at the new firm, I include the first four years of observations at that firm. Including the additional years after the arrival of the CEO at the new firm 
reduces concern about irregular compensation practices that might occur during the arrival year (large signing bonuses or compensation for only part of the fiscal year, for example). Table 13 breaks down compensation and industry-adjusted ROA for years relative to departing and arriving for the mover sample. Although there is slight variation in the compensation measures for incoming CEOs at the new firm (Panel B), none of the differences are statistically significant.

The compensation data for the CEOs at the prior firm are median values of the last four years that CEO was at the firm. Using these median values for compensation instead of the compensation during the last year at the prior firm reduces concern about irregular compensation that might occur during the departure year (for example, large severance pay or compensation for only part of the fiscal year). Table 13 shows that there is a little variation in the compensation measures for the incoming CEOs at their prior firm in Panel A; however, none of the differences are statistically significant. I continue to use the median values though to lessen the possibility of potential compensation irregularities occurring at the firm level.

All firm data for the incoming CEO's prior firm are from the last fiscal year that the $\mathrm{CEO}$ was at the prior firm. I do not take median values for the firm characteristics because they are not subject to the potential irregularities identified above for compensation. Because the compensation and financial values are being combined across different years, I adjust all of these values for inflation and present them as constant 1992 dollar amounts.

Table 14 presents the descriptive statistics for the CEO mover sample. Panel A and B show statistics for the incoming CEO at the new firm and prior firm, respectively. 
Mover CEOs at the new firm receive higher total compensation compared to their prior firm but a similar salary plus bonus. The new firms that hire the CEOs are larger and have worse operating performance (both stock return and ROA) than the CEO's prior firm. Panel C provides statistics on other variables used in the mover sample. Sixty-one percent of the mover CEOs can expect to receive a higher total compensation at their new firm than their prior firm, and forty seven percent move to a firm in the same industry as their prior firm. On average, it takes CEOs just over three years to go from their prior firm to the new firm.

Recent peak prices reference point

This sample uses the full Execucomp dataset that can be merged with CRSP pricing data. All compensation data comes from Execucomp, and I collect financial and return data from Compustat and CRSP.

Table 15 provides descriptive statistics for the peak price sample. The median percentage change from the fiscal year high price to fiscal year end price (high change 52 ) is $-13.5 \%$, whereas the median percentage change from the fiscal year low price to fiscal year end price (low change 52) is $32.5 \%$. The low change variable is positively skewed and has considerably more volatility than the high change variable, which is to be expected of stocks that have positive expected returns over the time periods analyzed.

\section{Empirical Results}

CEO mover sample - loss aversion 
Tables 16 and 17 report the regression results for the CEO mover sample. The dependent variable is the $\log$ (compensation) for the CEO at the new firm minus the $\log ($ compensation) of the $\mathrm{CEO}$ at the prior firm. Panel A measures compensation as total compensation and Panel B measures compensation as salary plus bonus. Table 16 uses the industry/size compensation to calculate the predicted gains and losses, and Table 17 uses the hedonic regression to calculate the predicted gains and losses. In Table 16, Panel A, predicted gains (losses) in compensation are associated with significant increases (decreases) in compensation from the prior firm to the new firm. The coefficient on the predicted loss in compensation is larger, although not statistically significant, than the coefficient on the predicted gain in compensation ( $\mathrm{p}$-value at the bottom of the table is .106). The results in Table 17 are similar, although the statistical significance of both the predicted gains and losses are not as high as Table 16. These results are not consistent with Hypothesis 1, which predicted that the magnitude of the coefficient on loss would be less than the magnitude of the coefficient on gain.

One possible interpretation of these results is that poorly performing CEOs who are fired, or asked to resign, are driving down the coefficient on the loss variable because they have to accept a lower compensation level reference point after their poor performance. In untabulated results, I interact indicator variables for below and above median ROA at the CEO's prior firm with the gain and loss variables. This method allows me to estimate different coefficients for incoming CEOs who performed well and incoming CEOs who performed poorly at their previous job. The results are qualitatively unchanged using this interaction. 


\section{CEO mover sample - anchoring}

To test for anchoring, I measure the compensation (both total and salary plus bonus) of the preceding CEO at the mover's new firm and subtract that compensation from the median compensation of an industry/size peer group. All of the compensation values are for the year prior to the incoming CEO's arrival at the new firm. A high anchor variable means that the preceding $\mathrm{CEO}$ was paid less than the median pay of peer industry/size firms. I take the cumulative distribution of the anchor variable to normalize it for the regression. Hypothesis 3 predicts that the anchor cdf coefficient will be significantly negative. In Panel A for both Tables 16 and 17, the anchor cdf coefficient is negative and statistically significant, consistent with Hypothesis 3 . These results suggest that the board uses the compensation of the incoming mover CEOs' predecessor when setting the incoming mover CEOs' compensation.

\section{Recent peak prices reference point}

Tables 19 and 20 report the results for tests of recent high and low prices acting as a reference point when setting compensation. Table 19 uses the log of total compensation as the dependent variable and Table 20 uses the log of salary plus bonus as the dependent variable. Panels A, B, and C of both tables use the 52-, 26-, and 13-week high and low price over the fiscal year, respectively.

Panel A in both tables and Panel B in Table 20 indicate that drops from the fiscal year high price to the end year price result in lower compensation. Surprisingly, the tables also show that larger increases from the fiscal year low price to the end year price are associated with lower compensation. The tests at the bottom of Table 19 (Panel A) and 
Table 20 (Panels A and B) indicate that the high change coefficient is significantly greater than the low change coefficient for the fiscal year measurement period. The other independent variables are consistent with prior studies on compensation with the exception of return volatility. Graham, $\mathrm{Li}$, and Qiu (2012) find that return volatility is positively related to compensation, whereas my results indicate a negative relationship. The discrepancy may be due to different measurement methods. I use volatility of daily returns over the fiscal year while Graham, Li, and Qiu use volatility of daily log returns over the past five fiscal years. Overall, the results when the fiscal year high and low prices are measured over the entire fiscal year are consistent with Hypothesis 2.

Panels B and C, which use the 26 and 13 weeks before the fiscal year to measure high and low change respectively, do not show a statistically significant relationship between compensation and the high and low change variables. Although the high change variable has a high correlation with the firm's stock return over the fiscal year (Table 21), it appears to be picking up additional explanatory power on compensation. The low change variable is also highly correlated to the firm's stock return, but is negatively related to compensation when the fiscal year sample is used.

\section{Conclusion}

This study examines the use of reference points in setting CEO compensation. I examine the reference points through the context in which they are used in two widely studied behavioral phenomena: prospect theory and anchoring-and-adjusting. Prospect theory was developed by Kahneman and Tversky (1979). The main aspects of prospect theory that I test are that decisions involving risk are driven by changes in status relative 
to a reference point and that losses are disliked more than equal-sized gains are liked (loss-aversion).

I use two samples to test for prospect theory preferences in CEO compensation. First, I use a sample of CEOs who move from one company to another to determine if the incoming CEO's prior compensation level acts as the reference point in this sample. Second, I use the full sample of CEOs in Execucomp and test if recent high and low prices act as reference points.

The results of the prospect theory tests are mixed. In the sample of CEOs who move from one company to another, I do not find evidence of the loss aversion property of prospect theory. In the full sample looking at recent high and low prices, I find evidence that the fiscal year high and low price are used as reference points when setting compensation and losses (changes from the fiscal year high price to end year price) decrease compensation more than gains (changes from the fiscal year low price to end year price) increase compensation. This finding is consistent with the loss aversion property of prospect theory.

The other behavioral phenomenon I examine in this paper is anchoring-andadjusting. Anchoring refers to a decision maker being influenced by an initial value (called the anchor) of an unknown quantity before estimating that quantity. Even though the initial value may be irrelevant to the decision at hand, it acts as a reference point that is used and subsequent estimations of the unknown quantity are made by gradually adjusting away from the initial value (anchor). Anchoring-and-adjusting is a similar phenomenon to prospect theory, but anchoring deals with the formation of beliefs, 
whereas prospect theory outlines how people perceive utility. Because of this difference, I define a separate reference point when testing for anchoring-and-adjusting.

To test for the use of anchoring-and-adjusting in CEO compensation, I again use the sample of CEOs that move from one company to another. The reference point I use in this test is the compensation for the incoming CEO's predecessor. I argue that if the predecessor CEO was paid more than a comparable CEO, anchoring by the board would suggest that the incoming $\mathrm{CEO}$ will also receive a higher compensation. My results are consistent with the board using the predecessor's compensation as an anchor. If the incoming CEO's predecessor was paid highly relative to their industry/size counterparts, the incoming CEO's compensation is positively affected. 
Figure 1: Prospect Theory Value Function

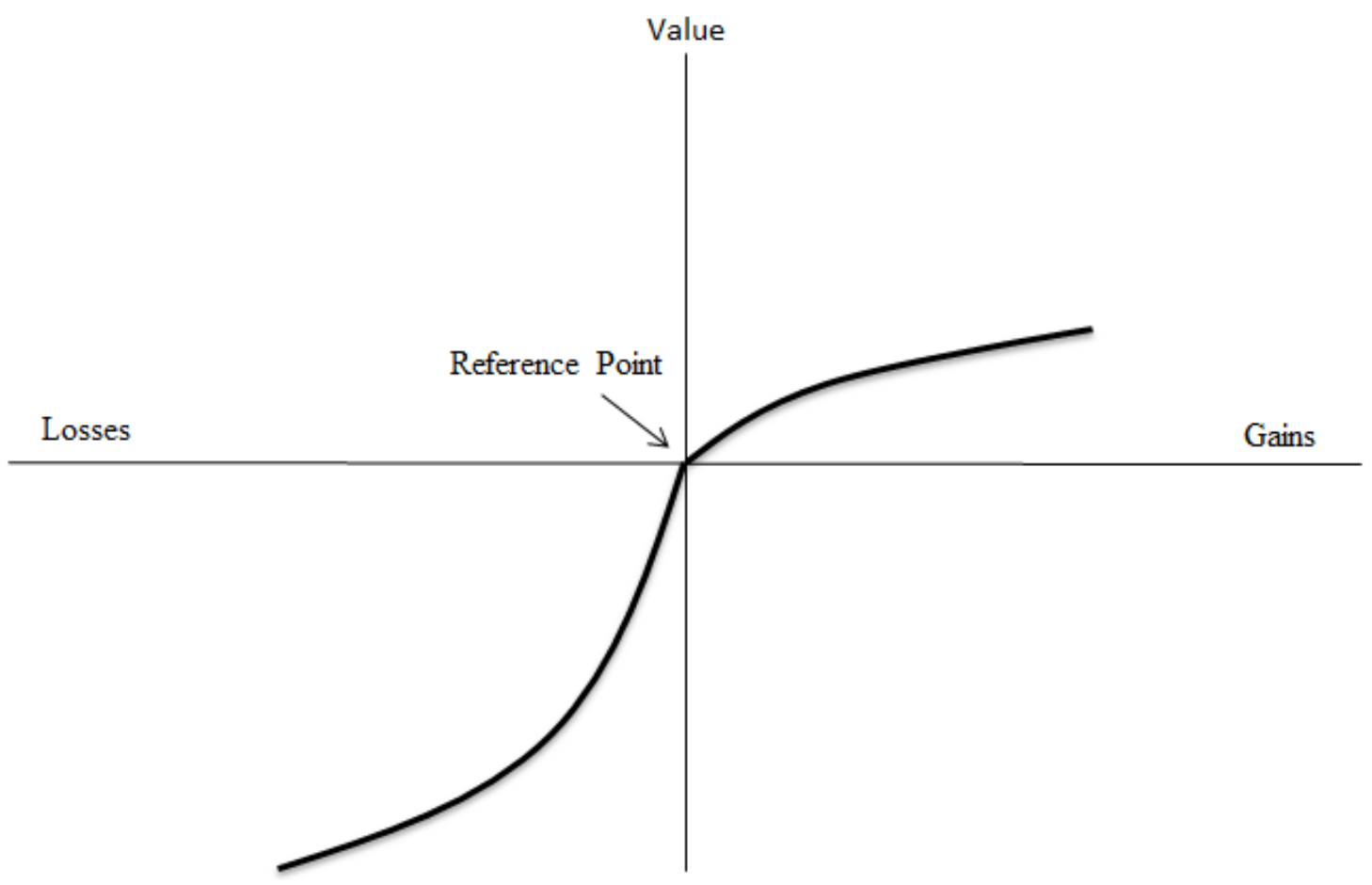


Table 13 - Compensation and performance by year relative to departure/arrival This table presents the log salary and bonus, log total compensation, and industry adjusted ROA for CEOs in the mover sample sorted by the fiscal year relative to departure (for incoming CEOs at prior firm) and arrival (for incoming CEOs at new firm). For the CEOs at the prior firm, I limit the sample in Panel A to CEOs who have compensation data for their departure year and three years prior to their departure (departure year is the reference year zero in Panel A). For the incoming CEOs, I limit the sample in Panel B to CEOs who have compensation data for their arrival year and the three years after arrival (arrival year is the reference year zero in Panel B). Compensation data are denominated in thousands of constant 1992 dollars.

\begin{tabular}{|c|c|c|c|c|c|c|c|c|c|c|}
\hline & \multicolumn{5}{|c|}{ Panel A - Incoming CEO at prior firm } & \multicolumn{5}{|c|}{ Panel B - Incoming CEO at new firm } \\
\hline & $\begin{array}{c}\text { Year } \\
\text { relative } \\
\text { to } \\
\text { departing } \\
\text { prior } \\
\text { firm } \\
\end{array}$ & $\mathrm{N}$ & Mean & Median & Std. Dev. & $\begin{array}{c}\text { Year } \\
\text { relative } \\
\text { to } \\
\text { arriving } \\
\text { at new } \\
\text { firm } \\
\end{array}$ & $\mathrm{N}$ & Mean & Median & Std. Dev. \\
\hline \multirow[t]{4}{*}{ Log salary + bonus } & 0 & 76 & 6.91 & 6.71 & 0.79 & 0 & 87 & 6.85 & 6.95 & 1.09 \\
\hline & -1 & 76 & 6.97 & 6.89 & 0.74 & 1 & 87 & 6.85 & 6.71 & 1.07 \\
\hline & -2 & 76 & 6.99 & 7.10 & 0.76 & 2 & 87 & 6.80 & 6.70 & 1.10 \\
\hline & -3 & 76 & 6.95 & 6.82 & 0.77 & 3 & 87 & 6.70 & 6.75 & 1.76 \\
\hline \multirow[t]{4}{*}{ Log total compensation } & 0 & 76 & 8.05 & 7.99 & 1.10 & 0 & 87 & 8.13 & 8.20 & 1.27 \\
\hline & -1 & 76 & 8.07 & 8.14 & 0.89 & 1 & 87 & 8.19 & 8.34 & 1.07 \\
\hline & -2 & 76 & 7.89 & 8.00 & 0.98 & 2 & 87 & 8.25 & 8.42 & 1.17 \\
\hline & -3 & 76 & 7.87 & 7.81 & 1.02 & 3 & 87 & 8.29 & 8.37 & 1.00 \\
\hline \multirow[t]{4}{*}{ Ind. adj. ROA } & 0 & 76 & 0.04 & 0.03 & 0.11 & 0 & 87 & -0.03 & 0.01 & 0.66 \\
\hline & -1 & 76 & 0.04 & 0.01 & 0.10 & 1 & 87 & 0.02 & 0.02 & 0.32 \\
\hline & -2 & 76 & 0.04 & 0.02 & 0.08 & 2 & 87 & 0.01 & 0.01 & 0.37 \\
\hline & -3 & 76 & 0.04 & 0.02 & 0.08 & 3 & 87 & 0.05 & 0.02 & 0.11 \\
\hline
\end{tabular}




\section{Table 14 - CEO movers descriptive statistics}

Panel A provides summary statistics for mover CEOs at their new firm. Panel B is for mover CEOs at their prior firm. Panel $\mathrm{C}$ contains data on other variables used in the CEO mover sample. Compensation data are denominated in thousands of constant 1992 dollars. Financial data are denominated in millions of constant 1992 dollars. Variables are defined in Appendix A.

\begin{tabular}{lrrrr} 
Panel A: Incoming CEO at new firm & & & & \\
\cline { 1 - 3 } Variable & & & & \\
Log total compensation & 588 & 8.12 & 8.18 & 1.17 \\
Log salary + bonus & 578 & 6.68 & 6.69 & 1.62 \\
Log total assets & 588 & 8.23 & 8.19 & 1.94 \\
Market to book & 588 & 1.96 & 1.40 & 4.29 \\
Stock return (fiscal year) & 585 & 12.46 & 5.20 & 58.65 \\
Stock return (three year) & 536 & 4.87 & 3.73 & 33.23 \\
ROA & 587 & 0.01 & 0.03 & 0.34 \\
\hline
\end{tabular}

Panel B: Incoming CEO at prior firm

\begin{tabular}{lrrrr} 
Variable & $\mathrm{N}$ & Mean & Median & Std dev \\
\hline Log total compensation & 584 & 7.73 & 7.71 & 0.98 \\
Log salary + bonus & 587 & 6.69 & 6.63 & 0.76 \\
Log total assets & 588 & 7.50 & 7.32 & 1.70 \\
Market to book & 584 & 2.00 & 1.50 & 1.55 \\
Stock return (fiscal year) & 574 & 20.42 & 11.02 & 52.56 \\
Stock return (three year) & 536 & 11.24 & 12.11 & 23.10 \\
ROA & 588 & 0.04 & 0.04 & 0.15 \\
\hline
\end{tabular}

Panel C: Other mover variables

\begin{tabular}{lcccc} 
Variable & N & Mean & Median & Std dev \\
\hline Gain & 584 & 0.46 & 0.29 & 0.54 \\
Loss & 588 & 0.30 & - & 0.55 \\
Gain $>$ 0 & 588 & 0.61 & 1.00 & 0.49 \\
Loss $>$ 0 & 588 & 0.38 & - & 0.49 \\
Anchor CDF & 458 & 0.53 & 0.50 & 0.30 \\
Log peer total compensation & 588 & 7.89 & 7.88 & 0.79 \\
Year difference & 149 & 3.63 & 3.00 & 2.85 \\
Prior Ind. Adj. ROA < 0 & 588 & 0.35 & - & 0.48 \\
Same Industry Move & 588 & 0.47 & - & 0.50 \\
Change in log total compensation & 584 & 0.38 & 0.52 & 1.17 \\
Change in log total assets & 588 & 0.72 & 0.88 & 1.43 \\
Change in market to book & 584 & -0.04 & -0.12 & 4.51 \\
\hline
\end{tabular}




\section{Table 15 - High and low change sample descriptive statistics}

This table provides summary statistics for the full Execucomp sample of CEOs that I use in the high and low change tests. Compensation data are denominated in thousands of dollars. Financial data are denominated in millions of dollars. Variables are defined in Appendix A.

\begin{tabular}{lcccc} 
Variable & $\mathrm{N}$ & Mean & Median & Std dev \\
\hline Log total compensation & 30,116 & 7.841 & 7.835 & 1.170 \\
Log salary plus bonus & 30,204 & 6.769 & 6.763 & 0.991 \\
High change 52 & 30,305 & -19.519 & -13.542 & 19.057 \\
Low change 52 & 30,305 & 52.135 & 32.58 & 88.736 \\
High change 26 & 30,305 & -15.086 & -9.76 & 15.919 \\
Low change 26 & 30,305 & 30.95 & 22.222 & 37.378 \\
High change 13 & 30,305 & -10.728 & -6.604 & 12.197 \\
Low change 13 & 30,305 & 20.828 & 14.583 & 24.094 \\
Log total assets & 30,345 & 7.462 & 7.328 & 1.764 \\
Market to book & 30,312 & 2.023 & 1.492 & 2.102 \\
Stock return & 30,318 & 17.452 & 10.048 & 64.821 \\
ROA & 30,338 & 4.825 & 4.833 & 15.676 \\
Return volatility & 30,324 & 9.884 & 5.516 & 78.786 \\
CEO chair indicator & 30,355 & 0.611 & 1.000 & 0.487 \\
Log tenure & 14,952 & 2.499 & 2.708 & 0.931 \\
\hline
\end{tabular}




\section{Table 16 - CEO movers regression using industry/size compensation to calculate gain/loss}

This table tests the determinants of changes in a CEO's compensation when the CEO moves from one company to another. The dependent variable is the log total compensation at the new firm the CEO goes to minus the median log total compensation (over the last four years) at the prior firm the CEO was at in Panel A. In Panel B, the dependent variable is the log salary plus bonus for the CEO at the new firm minus the median log salary plus bonus (over the last four years) at the prior firm the $\mathrm{CEO}$ was at. The gain and loss variables use an expected compensation measure at the new firm defined as the median compensation for the same industry/size group that the firm is in. Compensation data are denominated in thousands of constant 1992 dollars. Financial data are denominated in millions of constant 1992 dollars. Hetereoskedasticity-consistent t-statistics, clustered at the firm level, are reported by each coefficient. *,**,*** denote significance at the $10 \%$, $5 \%$, and $1 \%$ level respectively. Variables are defined in Appendix A.

Panel A

\begin{tabular}{lll} 
Dependent Variable - change in: & \multicolumn{2}{c}{$\log ($ total compensation) } \\
\cline { 2 - 3 } & Coefficient & T-stat \\
\hline Gain & $0.318^{* *}$ & 2.610 \\
Loss & $-0.619 * * *$ & -3.860 \\
Anchor CDF & $-0.473^{* * *}$ & -3.150 \\
Change in log total assets & $0.110^{*}$ & 1.780 \\
Change in market to book & 0.043 & 1.340 \\
Fiscal Year Stock return (new firm) & 0.000 & 0.410 \\
Fiscal Year Stock return (prior firm) & 0.000 & 0.010 \\
ROA & -0.005 & -1.200 \\
Return volatility & -0.007 & -1.010 \\
Log total compensation (prior firm) & $-0.148^{* *}$ & -2.140 \\
Prior Ind. Adj. ROA <0 & 0.135 & 0.880 \\
Same Industry Move & -0.156 & -1.340 \\
CEO and chair indicator & 0.217 & 1.350 \\
First year at new firm indicator & -0.036 & -0.430 \\
Year fixed effects & Yes & \\
\hline & & \\
Adjusted R-square & 0.388 & \\
Gain + Loss = 0 test p-value & 0.106 & \\
Number of observations & 444 & \\
\hline
\end{tabular}

Panel B

\begin{tabular}{ll}
\multicolumn{2}{c}{$\log$ (salary plus bonus) } \\
\hline Coefficient & T-stat \\
\hline 0.159 & 1.240 \\
0.209 & 0.650 \\
0.032 & 0.100 \\
0.082 & 0.780 \\
0.029 & 0.330 \\
0.001 & 0.830 \\
0.002 & 0.810 \\
-0.003 & -0.280 \\
-0.031 & -1.180 \\
$-0.285 * *$ & -2.170 \\
0.285 & 1.570 \\
0.021 & 0.100 \\
0.246 & 1.380 \\
$-0.177 *$ & -1.820 \\
Yes & \\
\hline
\end{tabular}

0.197

0.334

437 
Table 17 - CEO movers regression using a hedonic regression to calculate gain/loss This table tests the determinants of changes in a CEO's compensation when the CEO moves from one company to another. The dependent variable is the log total compensation at the new firm the CEO goes to minus the median log total compensation (over the last four years) at the prior firm the CEO was at in Panel A. In Panel B, the dependent variable is the log salary plus bonus for the CEO at the new firm minus the median log salary plus bonus (over the last four years) at the prior firm the CEO was at. The gain and loss variables use an expected compensation measure at the new firm defined using a hedonic regression. Compensation data are denominated in thousands of constant 1992 dollars. Financial data are denominated in millions of constant 1992 dollars. Hetereoskedasticity-consistent tstatistics, clustered at the firm level, are reported by each coefficient. *, **, *** denote significance at the $10 \%, 5 \%$, and $1 \%$ level respectively. Variables are defined in Appendix A.

Panel A

\begin{tabular}{lll} 
Dependent Variable: change in & \multicolumn{2}{l}{$\log ($ total compensation) } \\
\cline { 2 - 3 } & Coefficient & T-stat \\
\hline Gain & 0.331 & 1.330 \\
Loss & $-0.428^{* *}$ & -1.980 \\
Anchor CDF & $-0.320^{*}$ & -1.930 \\
Change in log total assets & 0.133 & 1.600 \\
Change in market to book & $0.063^{*}$ & 1.710 \\
Fiscal Year Stock return (new firm) & 0.000 & -0.380 \\
Fiscal Year Stock return (prior firm) & 0.001 & 0.700 \\
ROA & -0.007 & -1.230 \\
Return volatility & -0.013 & -1.510 \\
Log total compensation (prior firm) & $-0.211^{*}$ & -1.680 \\
Prior Ind. Adj. ROA < 0 & 0.055 & 0.400 \\
Same Industry Move & -0.119 & -1.030 \\
CEO and chair indicator & 0.173 & 0.900 \\
First year at new firm indicator & 0.010 & 0.120 \\
Year fixed effects & Yes \\
\hline & & \\
Adjusted R-square & 0.357 & \\
Gain + Loss = 0 test p-value & 0.641 & \\
Number of observations & 443 & \\
\hline
\end{tabular}

Panel B

\begin{tabular}{ll}
\multicolumn{2}{c}{$\log ($ salary plus bonus) } \\
\hline Coefficient & T-stat \\
\hline $0.988^{* * *}$ & 4.300 \\
$-0.983^{* * *}$ & -5.440 \\
0.129 & 0.450 \\
-0.115 & -1.110 \\
0.040 & 0.600 \\
0.000 & 0.250 \\
0.002 & 1.180 \\
-0.011 & -1.220 \\
-0.034 & -1.250 \\
-0.045 & -0.460 \\
0.050 & 0.350 \\
-0.033 & -0.190 \\
0.085 & 0.570 \\
$-0.170 *$ & -1.810 \\
Yes & \\
\hline
\end{tabular}

0.270

0.984

436 
Table 18 - CEO movers correlation matrix

The table reports Spearman correlation coefficients among variables from the CEO mover sample. Compensation data are denominated in thousands of constant 1992 dollars. Financial data are denominated in millions of constant 1992 dollars. Variables are defined in Appendix A.

\begin{tabular}{|c|c|c|c|c|c|c|c|c|c|c|c|}
\hline $\begin{array}{l}\text { hange in log } \\
\text { tal } \\
\text { ompensation }\end{array}$ & Gain & Loss & $\begin{array}{l}\text { Anchor } \\
\text { CDF }\end{array}$ & $\begin{array}{l}\text { Change } \\
\text { in log } \\
\text { total } \\
\text { assets }\end{array}$ & $\begin{array}{l}\text { Change } \\
\text { in } \\
\text { market } \\
\text { to book }\end{array}$ & $\begin{array}{l}\text { Stock } \\
\text { return } \\
\text { (new } \\
\text { firm) }\end{array}$ & $\begin{array}{l}\text { Stock } \\
\text { return } \\
\text { (prior } \\
\text { firm) }\end{array}$ & ROA & $\begin{array}{l}\text { Return } \\
\text { volatility }\end{array}$ & $\begin{array}{l}\text { Log total } \\
\text { compensation } \\
\text { (prior firm) }\end{array}$ & $\begin{array}{l}\text { Prior } \\
\text { Ind. } \\
\text { Adj. } \\
\text { ROA } \\
<0\end{array}$ \\
\hline
\end{tabular}

Change in log total compensation

Gain

Loss

Anchor CDF

Change in log total assets

Change in market to book

Stock return (new firm)

Stock return (prior firm)

ROA

Return volatility

Log total compensation (prior firm)

Prior Ind. Adj. ROA < 0

Same Industry Move

$\mathrm{CEO}$ and chair indicator
0.536

$-0.510 \quad-0.834$

$\begin{array}{lll}-0.132 & 0.038 & -0.092\end{array}$

$\begin{array}{llll}0.308 & 0.334 & -0.341 & 0.001\end{array}$

$\begin{array}{llll}0.087 & 0.132 & -0.134 & 0.104\end{array}$

$\begin{array}{llll}0.057 & 0.006 & -0.033 & 0.092\end{array}$

0.079

0.111

$-0.062$

$-0.421$

0.016

$-0.124$

0.126

$\begin{array}{lll}0.015 & -0.001 & -0.110\end{array}$

$\begin{array}{lll}0.132 & -0.181 & 0.178\end{array}$

$\begin{array}{lll}-0.122 & 0.213 \quad-0.020\end{array}$

$\begin{array}{lll}-0.629 & 0.563 & 0.056\end{array}$

$\begin{array}{lll}0.035 & 0.031 & 0.119\end{array}$

$\begin{array}{lll}-0.058 & 0.041 & -0.100\end{array}$

$\begin{array}{lll}-0.011 & -0.035 & -0.184\end{array}$

$-0.220$

$0.050 \quad 0.232$

$\begin{array}{lll}-0.008 & -0.250 \quad 0.007\end{array}$

$\begin{array}{llll}-0.028 & 0.298 & 0.276 & 0.010\end{array}$

$\begin{array}{llllll}-0.207 & -0.074 & -0.333 & 0.013 & -0.246\end{array}$

$\begin{array}{lllllll}0.025 & -0.119 & -0.015 & -0.028 & -0.113 & -0.035\end{array}$

$\begin{array}{lllllll}-0.156 & 0.250 & -0.014 & -0.136 & -0.096 & 0.054\end{array}$

$\begin{array}{lllllll}-0.093 & -0.061 & -0.067 & -0.044 & -0.147 & -0.011 & 0.152\end{array}$

$-0.108$

$\begin{array}{lllll}-0.014 & -0.137 & -0.026 & -0.035 & 0.094\end{array}$

$-0.034$

$0.047 \quad-0.049$ 


\section{Table 19 - High and low change regressions using total compensation}

This table reports regression results for the high and low change tests. Panel A uses the 52 week high and low price to construct the high change and low change variable. Panel B uses the 26 week high and low price to construct the high change and low change variable. Panel $\mathrm{C}$ uses the 13 week high and low price to construct the high change and low change variable. The dependent variable is the log total compensation for the fiscal year. Compensation data are denominated in thousands of dollars and financial data are denominated in millions of dollars. Hetereoskedasticity-consistent t-statistics are reported by each coefficient. *, $* *, * * *$ denote significance at the $10 \%, 5 \%$, and $1 \%$ level respectively. Variables are defined in Appendix A.

\begin{tabular}{|c|c|c|c|c|c|c|}
\hline \multirow[b]{3}{*}{ Independent variables } & \multicolumn{2}{|c|}{ Panel A } & \multicolumn{2}{|c|}{ Panel B } & \multicolumn{2}{|c|}{ Panel C } \\
\hline & \multicolumn{2}{|c|}{52 week high/low } & \multicolumn{2}{|c|}{26 week high/low } & \multicolumn{2}{|c|}{13 week high/low } \\
\hline & Coefficient & T-stat & Coefficient & T-stat & Coefficient & T-stat \\
\hline High change & $0.001 * *$ & 2.05 & -0.000 & -0.61 & -0.001 & -1.33 \\
\hline Low change & $-0.001 * * *$ & -6.26 & -0.000 & -1.1 & 0.000 & 1.3 \\
\hline Log total assets & $0.300 * * *$ & 27.84 & $0.298 * * *$ & 27.6 & $0.298 * * *$ & 27.67 \\
\hline Market to book & $0.033^{* * *}$ & 11.76 & $0.033 * * *$ & 11.66 & $0.033 * * *$ & 11.72 \\
\hline Stock return & $0.002 * * *$ & 12.13 & $0.001 * * *$ & 13.4 & $0.001 * * *$ & 13.95 \\
\hline Lag stock return & $0.001 * * *$ & 14.31 & $0.001 * * *$ & 14.5 & $0.001 * * *$ & 14.49 \\
\hline ROA & $0.004 * * *$ & 12.38 & $0.004 * * *$ & 12.64 & $0.004 * * *$ & 12.73 \\
\hline Lag ROA & $0.000 * *$ & 2.51 & $0.000 * *$ & 2.53 & $0.000 * *$ & 2.52 \\
\hline Return volatility & $-0.001 * *$ & -2.3 & $-0.003 * * *$ & -5.66 & $-0.004 * * *$ & -6.88 \\
\hline CEO chair indicator & $0.050 * * *$ & 3.98 & $0.049 * * *$ & 3.96 & $0.049 * * *$ & 3.95 \\
\hline Year and firm fixed effects & Yes & & Yes & & Yes & \\
\hline $\begin{array}{l}\text { Adjusted R-square } \\
\text { High change }- \text { Low change = }\end{array}$ & 0.659 & & 0.658 & & 0.658 & \\
\hline 0 test $p$-value & 0.0003 & & 0.885 & & 0.1234 & \\
\hline Number of observations & 29975 & & 29975 & & 29975 & \\
\hline
\end{tabular}




\section{Table 20 - High and low change regressions using salary plus bonus}

This table reports regression results for the high and low change tests. Panel A uses the 52 week high and low price to construct the high change and low change variable. Panel B uses the 26 week high and low price to construct the high change and low change variable. Panel $C$ uses the 13 week high and low price to construct the high change and low change variable. The dependent variable is the log salary plus bonus for the fiscal year. Compensation data are denominated in thousands of dollars and financial data are denominated in millions of dollars. Hetereoskedasticity-consistent t-statistics are reported by each coefficient. $*, * *, * * *$ denote significance at the $10 \%, 5 \%$, and $1 \%$ level respectively. Variables are defined in Appendix A.

Dependent variable $=\log ($ salary + bonus $)$

\begin{tabular}{|c|c|c|c|c|c|c|}
\hline \multirow[b]{3}{*}{ Independent variables } & \multicolumn{2}{|c|}{ Panel A } & \multicolumn{2}{|c|}{ Panel B } & \multicolumn{2}{|c|}{ Panel C } \\
\hline & \multicolumn{2}{|c|}{52 week high/low } & \multicolumn{2}{|c|}{26 week high/low } & \multicolumn{2}{|c|}{13 week high/low } \\
\hline & Coefficient & T-stat & Coefficient & T-stat & Coefficient & T-stat \\
\hline High change & $0.002 * * *$ & 6.81 & $0.001 * * *$ & 2.98 & -0.000 & -0.01 \\
\hline Low change & $-0.000 * * *$ & -4.11 & $-0.000 * * *$ & -2.94 & -0.000 & -0.79 \\
\hline Log total assets & $0.151 * * *$ & 14.61 & $0.148 * * *$ & 14.27 & $0.148 * * *$ & 14.3 \\
\hline Market to book & $0.007 * * *$ & 2.62 & $0.007 * *$ & 2.44 & $0.006^{* * *}$ & 2.37 \\
\hline Stock return & $0.001 * * *$ & 7.21 & $0.001 * * *$ & 10.41 & $0.001 * * *$ & 11.44 \\
\hline Lag stock return & $0.001 * * *$ & 8.35 & $0.001 * * *$ & 8.45 & $0.001 * * *$ & 8.44 \\
\hline ROA & $0.003 * * *$ & 9.55 & $0.003 * * *$ & 9.88 & $0.003 * * *$ & 10.08 \\
\hline Lag ROA & $0.000 * *$ & 2.46 & $0.000 * *$ & 2.46 & $0.000 * *$ & 2.46 \\
\hline Return volatility & $-0.002 * * *$ & -3.14 & $-0.003 * * *$ & -5.41 & $-0.004 * * *$ & -7.39 \\
\hline CEO chair indicator & $0.067 * * *$ & 5.6 & $0.067 * * *$ & 5.58 & $0.067 * * *$ & 5.58 \\
\hline Year and firm fixed effects & Yes & & Yes & & Yes & \\
\hline Adjusted R-square & 0.560 & & 0.559 & & 0.559 & \\
\hline High change - Low change $=0$ test $p$-value & $<.0001$ & & 0.0006 & & 0.773 & \\
\hline Number of observations & 30019 & & 30019 & & 30019 & \\
\hline
\end{tabular}


Table 21 - High and low change correlation matrix

The matrix reports Spearman correlation coefficients among variables from the high and low change sample. Compensation data are denominated in thousands of dollars and financial data are denominated in millions of dollars. Variables are defined in Appendix A.

\begin{tabular}{|c|c|c|c|c|c|c|c|c|c|c|c|c|}
\hline $\begin{array}{l}\text { Log total } \\
\text { compensation }\end{array}$ & $\begin{array}{l}\text { High } \\
\text { change } \\
52\end{array}$ & $\begin{array}{l}\text { Low } \\
\text { change } \\
52\end{array}$ & $\begin{array}{l}\text { High } \\
\text { change } \\
26\end{array}$ & $\begin{array}{l}\text { Low } \\
\text { change } \\
26\end{array}$ & $\begin{array}{l}\text { High } \\
\text { change } \\
13\end{array}$ & $\begin{array}{l}\text { Low } \\
\text { change } \\
13\end{array}$ & $\begin{array}{l}\mathrm{Log} \\
\text { total } \\
\text { assets }\end{array}$ & $\begin{array}{l}\text { Market } \\
\text { to book }\end{array}$ & $\begin{array}{l}\text { Stock } \\
\text { return }\end{array}$ & ROA & $\begin{array}{l}\text { Return } \\
\text { volatility }\end{array}$ & $\begin{array}{l}\text { CEO } \\
\text { chair } \\
\text { indicator }\end{array}$ \\
\hline
\end{tabular}

\begin{tabular}{|c|c|c|c|c|c|c|c|c|c|c|c|}
\hline 0.027 & 0.383 & & & & & & & & & & \\
\hline 0.098 & 0.905 & 0.372 & & & & & & & & & \\
\hline 0.022 & 0.291 & 0.834 & 0.362 & & & & & & & & \\
\hline 0.092 & 0.771 & 0.313 & 0.879 & 0.368 & & & & & & & \\
\hline-0.001 & 0.160 & 0.646 & 0.255 & 0.838 & 0.356 & & & & & & \\
\hline 0.568 & 0.186 & -0.161 & 0.181 & -0.138 & 0.180 & -0.133 & & & & & \\
\hline 0.073 & -0.100 & -0.027 & -0.087 & 0.001 & -0.086 & 0.016 & -0.324 & & & & \\
\hline 0.071 & 0.733 & 0.620 & 0.580 & 0.359 & 0.442 & 0.178 & -0.014 & -0.096 & & & \\
\hline 0.091 & 0.186 & 0.048 & 0.128 & -0.021 & 0.092 & -0.050 & -0.194 & 0.603 & 0.23033 & & \\
\hline-0.142 & -0.507 & 0.384 & -0.455 & 0.417 & -0.400 & 0.430 & -0.411 & 0.084 & -0.18281 & -0.151 & \\
\hline 0.123 & 0.080 & -0.038 & 0.071 & -0.047 & 0.074 & -0.041 & 0.183 & -0.042 & 0.03553 & 0.025 & -0.139 \\
\hline-0.002 & 0.103 & -0.110 & 0.092 & -0.115 & 0.082 & -0.111 & 0.196 & -0.012 & 0.0198 & 0.110 & -0.224 \\
\hline
\end{tabular}

Log total compensation

High change 26

Low change 26

High change 13

Low change 13

Log total assets

Market to book

Stock return

ROA

Return volatility

CEO chair indicator

Log tenure
$-0.00$

0.103

-

\begin{abstract}
$0.092-0.115$
\end{abstract}




\section{Appendix A: Variable Definitions}

Anchor CDF: The cumulative distribution function of the average comparable CEO compensation for the incoming CEO's predecessor minus the compensation for the incoming CEO's predecessor in the year prior to the incoming CEO's first observation at the new firm in Execucomp.

Bad skill/Bad luck: Indicator variable that is equal to one when skill/luck is negative and zero otherwise.

Bonus: Item Bonus from ExecuComp, the dollar value of a bonus earned during the fiscal year, measured in thousands of dollars.

Book-to-market: Ratio of book value to market value of equity. Data definitions follow Daniel and Titman (2006) and portions of code was used from the SIZE_BM sample program provided by Wharton Research Data Services (WRDS). In regressions where the dependent variable is change in log compensation, book-to-market is defined as the change in book-to-market.

CDF compensation distance: Cumulative distribution function (CDF) of compensation distance calculated each year for each industry-size group used to calculate compensation distance.

CEO chair indicator: Indicator variable equal to one if the CEO is also chairman of the board.

Compensation distance: The prior year median total compensation from the industry-size group (Fama-French 12 industries, 5 size groups based on market capitalization) minus the prior year total compensation of the firm in the same industry-size group. 
Divisions: The number of SIC codes listed for the pre-spinoff parent in SDC variable Target Ultimate Parent SIC. A separate SIC code is assigned to each line of business in which the pre-spinoff company is involved.

Firm stock return: Stock return for the spinoff firm with dividends reinvested calculated over the entire fiscal year.

Gain > 0 (Loss > 0): Indicator variable equal to one if Gain (Loss) is greater than zero and zero otherwise.

Gain: natural log of the average comparable CEO compensation minus the natural log of the incoming CEO's prior compensation, defined where the incoming CEO's prior compensation is less than the average comparable CEO compensation, and zero otherwise.

Herfindahl: The sum of the squared market share of all firms in the same Fama-French 12 industry for a given fiscal year. Market share is defined as firm-revenue divided by industry revenue.

High change: The percent change from the recent high price (most recent 13-, 26-, and 52- weeks before the fiscal year end) to the fiscal year end price. All prices are adjusted using CRSP's daily price adjustment factor.

Idiosyncratic variance: The variance of the residuals from regression Equation (2). Interlock: Indicator variable that takes a value of one if the CEO is involved in an interlock relationship that requires disclosure in the proxy statement and zero otherwise. Log revenue: Natural logarithm of the one-year lagged revenue. Revenue is denominated in millions of constant 1992 dollars. In regressions where the dependent variable is change in log compensation, log revenue is defined as the change in log revenue. Loss: natural log of the average comparable CEO compensation minus the natural log the incoming CEO's prior compensation, defined where the incoming CEOs prior 
compensation is more than the average comparable CEO compensation, and zero otherwise.

Low change: The percent change from the recent low price (most recent 13-, 26-, and 52weeks before the fiscal year end) to the fiscal year end price. All prices are adjusted using CRSP's daily price adjustment factor.

Low compensation indicator: Indicator variable that is equal to one when compensation distance is positive and zero otherwise.

Luck: The average daily excess return over the fiscal year minus skill. Multiplying by 250 annualizes luck.

Market beta: The sum of the coefficients on the market excess return and lag market excess return from a regression of daily firm excess returns on the daily Fama-French factors, momentum factor and one lag for each factor. The regressions use daily return data over the entire fiscal year.

Market to book: (Market value of equity plus the book value of debt)/total assets Option awards: ExecuComp item RSTKGRNT if OLD_DATAFMT_FLAG=1, STOCK_AWARDS_FV if OLD_DATAFMT_FLAG=0

Peer return (industry): Fiscal year return (dividends reinvested) for the equally-weighted portfolio of peer firms in the same Fama-French 12 industry, excluding the spinoff-firm stock return.

Peer return (industry-size): Fiscal year return (dividends reinvested) for the equally weighted portfolio of peer firms in the same Fama-French 12 industry and size quartile, excluding the spinoff-firm stock return.

Peer total compensation: median total compensation for a peer industry/size group (Fama-French 12 industries, 5 size groups based on market capitalization) 
Regulation: Indicator variable that takes a value of one if the firm is in the utilities industry (SIC code between 4900 and 4949) and zero otherwise.

Return volatility: The standard deviation of the daily percentage stock returns over the fiscal year.

ROA: Net income before extraordinary items and discontinued operations divided by the total book value of common equity

S\&P 500 return: Fiscal year return for the S\&P 500 (dividends reinvested).

Salary, Bonus, and Other compensation: ExecuComp items SALARY, BONUS, and OTHANN, respectively.

Skill: The intercept (alpha) from regressing daily excess firm stock returns on the daily Fama-French and momentum factors over the fiscal year during which the compensation occurs. To account for nonsynchronous trading, I also include one lag factor return for each factor similar to Lewellen and Nagel (2006). Multiplying by 250 annualizes skill. Stock grants: ExecuComp item OPTION_AWARDS_BLK_VALUE if OLD_DATAFMT_FLAG=1, OPTION_AWARDS_FV if OLD_DATAFMT_FLAG=0 Stock return (fiscal year): Item TRS1YR from ExecuComp, the one year total percentage return to shareholders with monthly reinvestment of dividends.

Stock return (three year): Item TRS3YR from ExecuComp, the three year total percentage return to shareholders with monthly reinvestment of dividends.

Tenure: The natural logarithm of the number of days the CEO has been in office as of each fiscal year end.

Total assets: Item at from Compustat, measured in millions of dollars.

Total compensation: Item TDC1 from ExecuComp, defined as the sum of salary, bonus, other annual compensation, long-term incentive payouts, other cash payouts, and the 
value of restricted stock and stock options granted (using Black-Scholes) measured in thousands of dollars. 


\section{References}

Aggarwal, R. K., \& Samwick, A. A. (1999). Executive compensation, strategic competition, and relative performance evaluation: Theory and evidence. The Journal of Finance, 54(6).

Ahn, S., \& Denis, D. J.. (2004). Internal capital markets and investment policy: evidence from corporate spin-offs. Journal of Financial Economics, 71, 489-516.

Albuquerque, A. (2009). Peer firms in relative performance evaluation. Journal of Accounting and Economics, 48(1), 69-89.

Albuquerque, A. (2014). Do growth-option firms use less relative performance evaluation?. The Accounting Review, 89(1), 27-60.

Albuquerque, A. M., De Franco, G., \& Verdi, R. S. (2013). Peer choice in CEO compensation. Journal of Financial Economics, 108(1), 160-181.

Amir, E. and Ganzach, Y. (1998). Overreaction and underreaction in analysts' forecasts. Journal of Economic Behavior \& Organization 37, 333-347.

Antle, R., \& Smith, A. (1986). An empirical investigation of the relative performance evaluation of corporate executives. Journal of Accounting Research, 24(1), 1-39.

Aron, D. J. (1991). Using the capital market as a monitor: corporate spinoffs in an agency framework. The Rand Journal of Economics, 505-518. 
Baker, M., Pan, X. and Wurgler, J. (2012). The effect of reference point prices on mergers and acquisitions. Journal of Financial Economics 106, 49-71.

Barberis, N. and Xiong, W. (2009). What Drives the Disposition Effect? An Analysis of a Long-Standing Preference-Based Explanation. Journal of Finance 64, 751-784.

Berger, P., \& Ofek, E. (1995). Diversification's effect on firm value. Journal of Financial Economics, 37, 39-65.

Bergman, O., Ellingsen, T., Johannesson, M. and Svensson, C. (2010). Anchoring and cognitive ability. Economics Letters 107, 66-68.

Bertrand, M., \& Mullainathan, S. (2001). Are CEOs rewarded for luck? The ones without principals are. The Quarterly Journal of Economics, 116(3), 901-932.

Bizjak, J. M., Lemmon, M. L., \& Naveen, L. (2008). Does the use of peer groups contribute to higher pay and less efficient compensation?. Journal of Financial Economics, 90(2), 152-168.

Bizjak, J.., Lemmon, M., and Naveen, L. (2008). Does the use of peer groups contribute to higher pay and less efficient compensation? Journal of Financial Economics 90, 152168.

Bizjak, J., Lemmon, M., \& Nguyen, T. (2011). Are all CEOs above average? An empirical analysis of compensation peer groups and pay design. Journal of Financial Economics, 100(3), 538-555. 
Black, D., Dikolli, S., \& Hofmann, C. (2011). Peer group composition, peer performance aggregation, and detecting relative performance evaluation. Working Paper, Duke University, and Munich School of Management.

Bokhari, S. and Geltner, D. (2011). Loss aversion and anchoring in commercial real estate pricing: Empirical evidence and price index implications. Real Estate Economics 39, 635-670.

Burch, T.R., \& Nanda, V. (2003). Divisional Diversity and the Conglomerate Discount: Evidence from Spin-offs. Journal of Financial Economics, 70, 69-98.

Camerer, C.F., Loewenstein, G. and Rabin, M. (2011). Advances in Behavioral Economics. Princeton University Press.

Campbell, S.D. and Sharpe, S.A. (2009). Anchoring bias in consensus forecasts and its effect on market prices. Journal of Financial and Quantitative Analysis 44, 369-390.

Chemmanur, T. J., \& Yan, A. (2004). A theory of corporate spin-offs. Journal of Financial Economics, 72(2), 259-290.

Chen, M.K., Lakshminarayanan, V. and Santos, L.R. (2006). How basic are behavioral biases? Evidence from capuchin monkey trading behavior. Journal of Political Economy 114, 517-537.

Cremers, M. \& Grinstein, Y. (2014) Does the Market for CEO Talent Explain Controversial CEO Pay Practices?. Review of Finance, 18(3), 921-960. 
Cusatis, P. J., Miles, J. A., \& Woolridge, J. R. (1993). Restructuring through spinoffs: The stock market evidence. Journal of Financial Economics, 33(3), 293-311.

Daley, L., Mehrotra, V., \& Sivakumar, R. (1997). Corporate focus and value creation Evidence from spinoffs. Journal of Financial Economics, 45(2), 257-281.

Daniel, N. D., Li, Y. \& Naveen, L. (2012). No Asymmetry in Pay for Luck (October 10, 2012). Working Paper. Available at SSRN: http://ssrn.com/abstract=2160015 or http://dx.doi.org/10.2139/ssrn.2160015

De Angelis, D., \& Grinstein, Y. (2011). Relative performance evaluation in CEO Compensation: Evidence from the 2006 disclosure rules. Johnson School Research Paper Series, (39-2010).

Denis, D. J., Denis, D. K., \& Walker, M. D. (2012). Matching directors with firms: Evidence from board structure following corporate spinoffs (October 12, 2012). Working Paper. Available at SSRN: http://ssrn.com/abstract=2162549 or http://dx.doi.org/10.2139/ssrn.2162549

Desai, H., \& Jain, P. C. (1999). Firm performance and focus: long-run stock market performance following spinoffs. Journal of Financial Economics, 54(1), 75-101.

Dittmann, I., Maug, E. and Spalt, O. (2010). Sticks or carrots? Optimal CEO compensation when managers are loss averse. Journal of Finance 65, 2015-2050. 
Faulkender, M., \& Yang, J. (2010). Inside the black box: The role and composition of compensation peer groups. Journal of Financial Economics, 96(2), 257-270.

Faulkender, M., \& Yang, J. (2013). Is disclosure an effective cleansing mechanism? The dynamics of compensation peer benchmarking. Review of Financial Studies, 26(3), 806839.

Frydman, C., \& Jenter, D. (2010). CEO compensation (No. w16585). National Bureau of Economic Research.

Garvey, G., \& Milbourn, T. (2003). Incentive compensation when executives can hedge the market: Evidence of relative performance evaluation in the cross section. The Journal of Finance, 58(4), 1557-1582.

Garvey, G. T., \& Milbourn, T. T. (2006). Asymmetric benchmarking in compensation: Executives are rewarded for good luck but not penalized for bad. Journal of Financial Economics, 82(1), 197-225.

Gertner, R., Powers E., and Scharfstein, D. (2002). Learning about internal capital markets from corporate spin-offs. Journal of Finance, 57, 2479-2506.

Gibbons, R., \& Murphy, K. J. (1990). Relative Performance Evaluation for Chief Executive Officers. Industrial and Labor Relations Review, 30S-51S. 
Gong, G., Li, L. Y., \& Shin, J. Y. (2011). Relative performance evaluation and related peer groups in executive compensation contracts. The Accounting Review, 86(3), 10071043.

Gopalan, R., Milbourn, T., \& Song, F. (2010). Strategic flexibility and the optimality of pay for sector performance. Review of Financial Studies, 23(5), 2060-2098.

Graham, J.R., Li, S. and Qiu, J. (2012). Managerial attributes and executive compensation. Review of Financial Studies 25, 144-186.

Hite, G. L., \& Owers, J. E. (1983). Security price reactions around corporate spin-off announcements. Journal of Financial Economics, 12(4), 409-436.

Holmstrom, B. (1979). Moral hazard and observability. The Bell Journal of Economics, $10,74-91$.

Holmstrom, B. (1982). Moral hazard in teams. The Bell Journal of Economics, 324-340.

Holmstrom, B., \& Kaplan, S. N. (2003). The state of US corporate governance: what's right and what's wrong?. Journal of Applied Corporate Finance, 15(3), 8-20.

Huddart, S., Lang, M. and Yetman, M.H. (2009). Volume and price patterns around a stock's 52-week highs and lows: Theory and evidence. Management Science 55, 16-31.

Kahneman, D. (1992). Reference points, anchors, norms, and mixed feelings. Organizational Behavior and Human Decision Processes 51, 296-312. 
Kahneman, D. and Tversky, A. (1979). Prospect theory: An analysis of decision under risk. Econometrica: Journal of the Econometric Society, 263-291.

Kahneman, D. and Tversky, A. (2000). Choices, values, and frames. Cambridge University Press.

Krishnaswami, S., \& Subramaniam, V. (1999) Information asymmetry, valuation, and the corporate spin-off decision. Journal of Financial economics, 53, no. 1: 73-112.

Lewellen, J. \& Nagel, S. (2006). The Conditional CAPM Does Not Explain Asset-Pricing Anomalies. Journal of Financial Economics, 82, 289-314.

Li, Q., \& Reis, E. (2009). Managerial Compensation and Firm Value: Evidence from Corporate Spinoffs (May 2009). Working Paper, Dillard College of Business Administration and Bentley University.

Maxwell, W. F., \& Rao, R. P. (2003). Do Spin-offs Expropriate Wealth from Bondholders?. The Journal of Finance, 58(5), 2087-2108.

McConnell, J. J., Ozbilgin, M., \& Wahal, S. (2001). Spin-offs, Ex Ante*. The Journal of Business, 74(2), 245-280.

Miles, J. A., \& Rosenfeld, J. D. (1983). The Effect of Voluntary Spin-off Announcements on Shareholder Wealth. The Journal of Finance, 38(5), 1597-1606. 
Northcraft, G.B. and Neale, M.A. (1987). Experts, amateurs, and real estate: An anchoring-and-adjustment perspective on property pricing decisions. Organizational Behavior and Human Decision Processes 39, 84-97.

Parrino, R. (1997). Spinoffs and wealth transfers: The Marriott case. Journal of Financial Economics, 43(2), 241-274.

Post, T., Van den Assem, M.J., Baltussen, G. and Thaler, R.H. (2008). Deal or no deal? decision making under risk in a large-payoff game show. The American Economic Review, 38-71.

Pyo, U. (2007). Enhancing managerial incentives and value creation: Evidence from corporate spinoffs. Journal of Economics and Finance, 31(3), 341-358.

Rajgopal, S., Shevlin, T., \& Zamora, V. (2006). CEOs' outside employment opportunities and the lack of relative performance evaluation in compensation contracts. The Journal of Finance, 61(4), 1813-1844.

Schipper, K., \& Smith, A. (1983). Effects of recontracting on shareholder wealth: The case of voluntary spin-offs. Journal of Financial Economics, 12(4), 437-467.

Seward, J. K., \& Walsh, J. P. (1996). The governance and control of voluntary corporate spin-offs. Strategic Management Journal, 17(1), 25-39.

Shefrin, H., \& Statman, M. (1985). The disposition to sell winners too early and ride losers too long: Theory and evidence. Journal of Finance 40, 777-790. 
Tversky, A. and Kahneman, D. (1974). Judgment under uncertainty: Heuristics and biases. Science 185, 1124-1131. 


\section{VITA}

Scott William O’Brien was born and raised in Brookings, South Dakota. He completed his undergraduate degrees from Belmont University in 2010, majoring in finance and math. Upon graduating from Belmont, Scott joined the doctoral program at the University of Missouri as a $\mathrm{PhD}$ student in finance. 